4 nordon 



\section{Nordic Biodiversity Beyond 2010}

Challenges and Experiences in Global Perspective 


\section{Nordic Biodiversity Beyond 2010}

Challenges and Experiences in Global Perspective

TemaNord 2010:526

(C) Nordic Council of Ministers, Copenhagen 2010

ISBN 978-92-893-2028-3

Cover photo: Karin Beate Nøsterud

This publication is available as Print on Demand (PoD) and can be ordered on

www.norden.org/order. Other Nordic publications are available at www.norden.org/en/publications.

\section{Nordic Council of Ministers}

Ved Stranden 18

DK-1061 København K

Phone (+45) 33960200

Fax (+45) 33960202

www.norden.org

\author{
Nordic Council \\ Ved Stranden 18 \\ DK-1061 København K \\ Phone (+45) 33960400 \\ Fax (+45) 33111870
}

\section{Nordic co-operation}

Nordic co-operation is one of the world's most extensive forms of regional collaboration, involving Denmark, Finland, Iceland, Norway, Sweden, and three autonomous areas: the Faroe Islands, Greenland, and Åland.

Nordic co-operation has firm traditions in politics, the economy, and culture. It plays an important role in European and international collaboration, and aims at creating a strong Nordic community in c strong Europe.

Nordic co-operation seeks to safeguard Nordic and regional interests and principles in the global community. Common Nordic values help the region solidify its position as one of the world's most innovative and competitive. 


\section{Content}

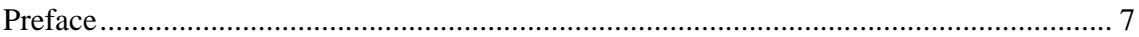

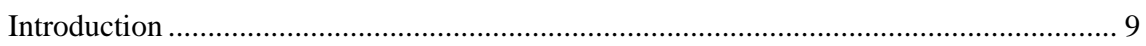

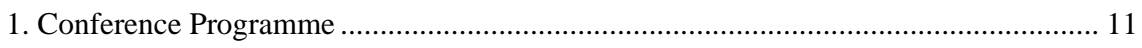

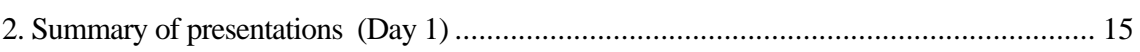

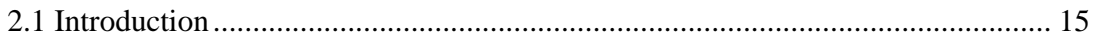

2.2 Theme 1 - Nordic biodiversity status, trends and monitoring tools ..................... 22

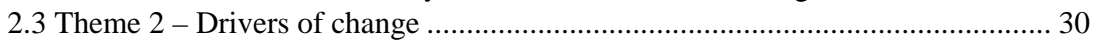

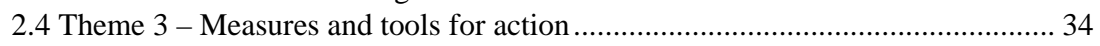

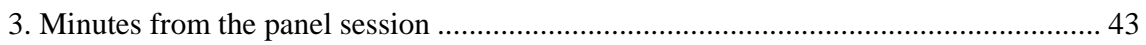

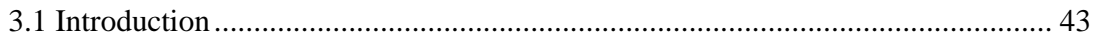

3.2 Stig Johansson, Nordic Council of Ministers ..................................................... 43

3.3 Jiska van Dijk, Norwegian Institute for Nature Research........................................ 44

3.4 Marina von Weissenberg, Ministry of the Environment, Finland.......................... 45

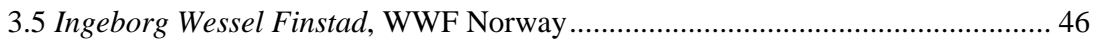

3.6 Ulrika Berggren, Swedish Forest Agency, Sweden ............................................. 47

3.7 Ole Dahlqvist Sørensen, Allerød Borough Council, Denmark ............................. 49

3.8 From the discussion and questions from the Chair ............................................. 51

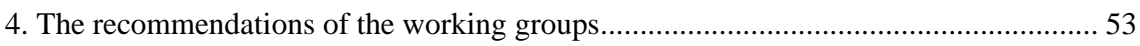

4.1 Group 1 - Setting new targets for biodiversity beyond 2010 ............................. 53

4.2 Group 2 - Setting new targets for drivers of change beyond 2010 ...................... 55

4.3 Group 3 - Main instruments for mainstreaming biodiversity ................................... 57

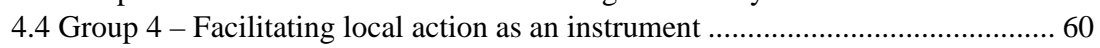

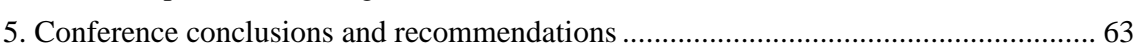

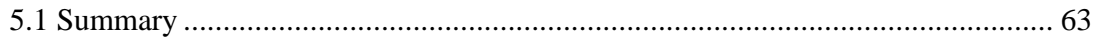

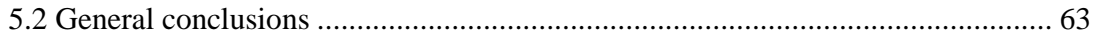

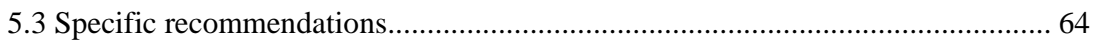

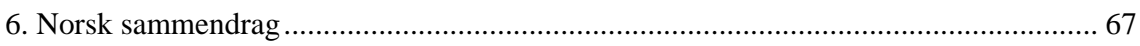

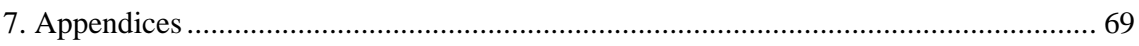

7.1 Background paper for workshop 1: Setting new targets

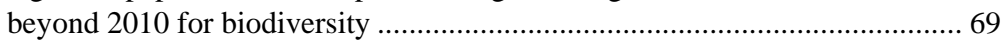

7.2 Background paper for workshop 3: Tools for mainstreaming biodiversity .......... 72

7.3 Background paper for workshop 4: Facilitating local action ...................................... 74 



\section{Preface}

We all depend on biodiversity, but we must make biodiversity relevant to people. The long-term loss of nature and biodiversity is, however, not as easily translated into clear messages, let alone economic opportunities, as are measures to tackle climate change. The changes are dispersed, and often act slowly and subtly. Connecting the economic problems and threats people face due to the degradation of our biological resources is also frequently hard to express in facts and figures, as we have seen with the efforts to replicate the review of the economic impacts of climate change.

Yet we all see the impact of degradation and loss of biodiversity in our daily lives when we are hiking, fishing, hunting and enjoying nature. We must create a vision and a powerful metaphor, communicated to and understood by ordinary people, that describes our co-existence with and dependence upon nature and how the loss of nature reflects on ourselves as Nordic people and societies. The need to stop the loss of biodiversity does not end in 2010. What will we call upon now? That is our challenge. 



\section{Introduction}

On 26-27 October 2009, the Nordic Council of Ministers hosted a Nordic symposium on biodiversity in Trondheim, Norway. The title chosen for this symposium was Nordic Biodiversity Beyond 2010 - Challenges and Experiences in Global Perspective. The aim was to take stock of Nordic biodiversity and look beyond 2010. About 70 participants from all the Nordic countries gathered in Trondheim for two days to start this work. They represented public authorities, non-governmental organisations and research institutions concerned with the goal of halting the loss of biodiversity in the Nordic countries.

Content of the symposium

The symposium concentrated on three themes:

- Nordic biodiversity: status, trends and tools for monitoring

- Drivers of change: What is the status of the drivers that influence biodiversity in a negative or positive way? Further actions?

- Measures and tools for action: What measures have the Nordic countries taken to preserve and enhance biodiversity? How do they relate to the 2010 target?

On the first day, lectures were held on the above mentioned three themes. On the second day, the participants were divided into four working groups. Based on proposed topics for discussion, the participants were requested to arrive at recommendations for further action.

The targets for these recommendations were:

- Nordic input to European and global processes leading towards highlevel political decisions for setting post-2010 biodiversity targets in autumn 2010 (to be set by the COP10 of the CBD and/or the United Nations General Assembly)

- Practical follow-up and policy implementation in the Nordic countries and under the Nordic Council of Ministers.

The conference programme was prepared by a Programme Committee coordinated by Lars Ekker and Ingvild Kalland at the Norwegian Directorate for Nature Management. The members of the Programme Committee were Bo Normander of the Danish National Environmental Research Institute, Gudrun Schneider, Tone Solhaug and Kristin Teien Thorsrud of the Norwegian Ministry of the Environment, Margareta Ihse of the Swedish Scientific Council for Biodiversity, Marina von Weissenberg of the Finnish Ministry of the Environment, Inge Thaulow of the Ministry of Domestic Affairs, Na- 
ture and Environment, Greenland and Sigurdur Thrainsson of the Ministry for the Environment, Iceland.

The Norwegian Directorate for Nature Management (DN) was responsible for organising the symposium.

This document is based on the minutes from the presentations, the panel discussion and the working group discussions. It also contains the Chairman's conclusions and recommendations based on the presentations and discussions at the symposium.

This report and the presentations given at the conference can also be found at the conference home page at http://www.dirnat.no/symposium2010/ 


\section{Conference Programme}

Day 1 - 26 October 2009

09.00-10.00 Registration

10.00-10.20 Opening speech by the Norwegian State Secretary Heidi Sørensen, the Norwegian Ministry of the Environment

10.20-10.25 Welcome to Trondheim, Deputy Mayor Knut Fagerbakke, Trondheim City Council

10.25-10.35 General information by the symposium chairman, Stig Johansson - chairman of the Terrestrial Ecosystem Group, Nordic Council of Ministers

10.35-10.55 Nordic contribution to international biodiversity implementation and post-2010 processes, Peter Johan Schei - Director of the Fridtjof Nansen Institute

Theme 1 - Nordic biodiversity status, trends and monitoring tools

Moderator: Berit Lein - Assistant Director General, Norwegian Directorate for Nature Management

10.55-11.15 State of biodiversity in the Nordic countries - status, monitoring tools and future challenges, Bo Normander - Danish National Environmental Research Institute

11.15-11.35 Nordic Red Lists of Threatened Species and Habitat Types, John Atle Kålås Norwegian Biodiversity Information Centre

11.35-11.55 Coffee Break

11.55-12.15 The Nordic input to SEBI 2010, Frederik Schutyser - European Environment Agency

12.15-12.35 The Finnish biodiversity indicators, Ari-Pekka Auvinen - Finnish Environment Institute

12.35-12.55 The Norwegian Nature Index, Signe Nybø - Norwegian Directorate for Nature Management

12.55-13.55 Lunch

Theme 2 - Drivers of change

Moderator: Axel Wenblad - Director General, Swedish Board of Fisheries

13.55-14.15

14.15-14.35

14.35-14.55

14.55-15.15

15.15-15.45

Main threats to biodiversity in the Nordic countries, Christian Steel - Norwegian Biodiversity Network

Climate change - what is happening to Nordic nature? Maria Mikkelsen representative from the Nordic indicators on climate change project

The acidification of the oceans, Jan Helge Fosså - Norwegian Institute of Marine Research

Changes in land use and fragmentation, Erik Framstad - Norwegian Institute for Nature Research

Coffee Break 
Theme 3 - Measures and tools for action

Moderator: Marina von Weissenberg - Senior Adviser, Finnish Ministry of the Environment

15.45-16.05 Nature conservation as a tool in the Nordic countries, Stig Johansson - Terrestrial Ecosystem Group, Nordic Council of Ministers

16.05-16.25 NOBANIS - a future tool to combat alien species, Harry Helmisaari - Finnish Environment Institute

16.25-16.45 Ecosystem-based marine management in the Nordic countries, Jorid Hammersland - Swedish Environmental Protection Agency

16.45-16.55 Short Break

16.55-17.15 Local participation - experience and future possibilities towards 2010, Terje Klokk - Norwegian Directorate for Nature Management

17.15-17.25 The Norwegian postcard campaign in 2008, Sissel Rübberdt - Norwegian Directorate for Nature Management

17.25-17.45 Enhancing synergies among biodiversity-related MEAs, Niko Urho - Finnish Ministry of the Environment

17.45-17.55 Announcements

$19.00 \quad$ Conference dinner - Rica Nidelven Hotel

Day 2 - 27 October 2009

09.00-13.00 Morning session

09.00-10.30 Panel session

\section{Questions:}

How has the 2010 target affected your work or field? Has the 2010 target been important to you? If so, why? Has the 2010 target gained sufficient political attention in your country? How can a post-2010 target be formulated to ensure that your field of work helps to safeguard biodiversity and ecosystem services?

Session leader:

Tone Solhaug, Ministry of the Environment, Norway

Panel participants:

Stig Johansson, Nordic Council of Ministers

Jiska van Dijk, Norwegian Institute for Nature Research

Marina von Weissenberg, Ministry of the Environment, Finland

Ingeborg Wessel Finstad, WWF Norway

Ulrika Berggren, Swedish Forest Agency

Ole Dahlqvist Sørensen, Allerød Borough Council, Denmark

\subsection{0-12.00 Working group session}

- Setting new targets beyond 2010 for biodiversity, Bo Normander Senior Adviser, National Environmental Research Institute 
- Setting new targets beyond 2010 for drivers of change, Reidar Hindrum - Senior Adviser, Norwegian Directorate for Nature Management

- Main instruments for mainstreaming biodiversity, Axel Wenblad Director General, Swedish Board of Fisheries

- Facilitating local action as an instrument, Stefan Skog - Director of the Environmental Division, Vanda Borough Council, Finland

12.00-13.00 Presentation of the recommendations of working groups

13.00-14.00 Lunch

14.00-16.00 Afternoon session

Session leaders:

Stig Johansson, Terrestrial Ecosystem Group, Nordic Council of Ministers and Symposium Chairman

Peter Johan Schei, Director, Fridtjof Nansen Institute

Plenary discussion leading up to recommendations for future action based on experiences from a Nordic perspective.

The targets for these recommendations are:

- Nordic input to European and global processes leading to high-level political decisions to set post-2010 biodiversity targets in autumn 2010 (to be set by COP10 of the CBD and/or the United Nations General Assembly)

- Practical follow-up and policy implementation in the Nordic countries and under the Nordic Council of Ministers

16.00 End of Day 2 



\section{Summary of presentations (Day 1)}

\subsection{Introduction}

\subsubsection{Opening speech}

Heidi Sørensen, State Secretary, Norwegian Ministry of the Environment

We are facing two major environmental challenges today: climate change and biodiversity loss.

Climate change is an increasing threat to biodiversity. On the other hand, robust ecosystems are a security and a safety net against climate change. We have to manage nature, aiming for resilient and robust ecosystems, and we must, as far as possible, reduce other negative stresses on bio-diversity. We are here in Trondheim to discuss biodiversity and how the Nordic countries can help to meet this global challenge.

The 2010 target has improved our way of working and has gained political attention, but a more focused follow-up effort is necessary for the post-2010 regime. I am glad to be here in Trondheim, the Norwegian biodiversity city, to take stock of where we are and to discuss the next steps to save our biodiversity.

The 2010 target has been valuable for many important achievements like the Nature Diversity Act, the Nature Index for Norway, the Norwegian Species Project and general improvements in our basic knowledge of biodiversity. However, the most important one is the Nature Diversity Act, which was approved by the Norwegian Parliament in June 2009 and came into force on 1 July 2009. This Act is one of Norway's most important followups of the Convention on Biological Diversity. The 2010 target gave us the necessary political momentum to finalise it. It is the most important nature legislation ever enacted in Norway. The Nature Diversity Act applies to all aspects of nature, from habitats and species to the genetic diversity within species. It is not only about conservation in protected areas, but also covers many principles and rules for sustainable use. It addresses both genetic resources and alien species, and is an Act for the future. It applies to all sectors that regulate the use of the natural environment in Norway.

The Nature Diversity Act has different levels of provisions:

- Protected Areas

- Areas and species requiring special focus

- General principles, etc. - provisions that apply to all nature conservation 
Three environmental principles are included in the Act. These are the precautionary principle, the principle of ecosystem approach and cumulative effect, and the user pays principle. Decisions should be based on knowledge - scientific knowledge and traditional knowledge.

Prior to this Act, Norway had no overall provisions for nature management outside protected areas, but we now have common regulations for these areas. Valuable nature will be secured by further regulations on sustainable use. Selected habitat types require special consideration by all the sectors when they are taking their decisions and planning projects that may have negative impacts on nature and the environment. Local authorities will have a special responsibility through their land-use planning. Action plans should be prepared for selected habitat types, and economic instruments will support the necessary actions.

The Act will also include protected areas. We will attempt to complete the National Park Plan in 2010. As of 2009, $15.7 \%$ of mainland Norway is protected. From 2010, more focus will be put on essential management in the protected areas.

The Nature Index for Norway is an instrument to measure and communicate the long-term trends in Norwegian nature. The project started in 2007 and has developed a new methodology. The index is calculated on the basis of a set of many different indicator species from a variety of habitats. Altogether, it says something about the total ecological state and trends over time for the different habitat types. The report for central Norway was published in February this year. The ecological status was $70 \%$ compared to the baseline. The results were in accordance with the general impression of the good ecological state of the natural environment in the area. They suggest that nature is in its worst state in open lowlands, the open sea, forests and coastal waters, whereas it is good in alpine, freshwater and wetland ecosystems. The nature index for all of Norway will be presented in September 2010.

The Norwegian Species Project finally got underway in 2009. It will be implemented in close cooperation with the Swedish species project, and is an example of good Nordic cooperation. The project should give us crucial knowledge about our species. How can we know if and when we halt the loss of biodiversity if we do not know how many and which species we have?

In addition to the species project, the overall level of basic knowledge has been improved. The Norwegian Biodiversity Information Centre began to function in 2005 and has provided us with a Norwegian Red List for Threatened Species in 2006, a Norwegian Black List for Alien Species in 2007, databases, etc. A brand new nature classification system was launched in 2009. A new edition of the Red List for Threatened Species and the first Red List for Threatened Habitat Types will be published in 2010. A new edition of the Black List will come in 2011.

We have to improve the interface between science and policy for biodiversity and ecosystem services at all levels. The ongoing process under UNEP to establish an Intergovernmental Platform on Biodiversity and Ecosystem Ser- 
vices is important. A parallel to the intergovernmental panel on climate change is needed for biodiversity. Authoritative know-ledge is required if we are to take the right decisions. Norway and the other Nordic countries are active in the ongoing work aimed at establishing such a platform.

Norway realises the value of placing increased focus on the importance of ecosystem services and therefore supports The Economics of Eco-systems and Biodiversity (TEEB) study. We have a moral and an ethical responsibility for biodiversity, but we greatly welcome other instruments and sources of information to provide a broader range of arguments. The TEEB work has a huge potential for giving us economic facts that underpin why biodiversity matters. It has recommended a reform of national income accounting to improve the management of natural resources. I would like to endorse the statement by Pavan Sukhdev: "We cannot manage what we do not measure". Knowledge from TEEB will help to make the case for a reform in this area.

The recently published report, "Signs of Climate Change in Nordic Nature", gives some examples of ongoing changes on multiple scales in the Nordic countries. Biodiversity is an important part of the solution to climate change. It provides a security and an insurance function for human wellbeing in relation to climate change, including being a buffer for unforeseen events and providing options for future solutions. I think it will be important that the Nordic countries cooperate on future biodiversity management and conservation because climate change gives us new challenges, such as climate refugees and more invasive species.

In many cases, it is more cost-effective and efficient to invest in biodiversity to mitigate and adapt to climate change. Reducing Emissions from Deforestation and Forest Degradation (REDD) is a good example and represents a win-win situation: good for climate, good for biodiversity and good for indigenous peoples who live in forests. We need to ensure that mitigation activities, including production of bio-energy, take due consideration of biodiversity. We need sustainable solutions, and we should aim for win-win situations. Climate change is an added stress on biodiversity. Other stresses must therefore be reduced, particularly those related to fragmentation, land conversion, invasive species, pollution and over-exploitation.

Ecosystems and biodiversity represent essential parts of a sustainable solution for climate change. They have to be integrated in a mutually supportive way to prevent unwanted consequences for both biodiversity and climate change.

I would also underline that the global 2010 biodiversity target has been important for the development of the Convention on Biological Diversity. At the global level, we managed to gain acceptance for the use of indicators, and this has been an improvement with regard to defining subtargets and timelines for decisions. What we really lack is measures to improve compliance worldwide.

So, where do we go? We need a long-term global vision and short-term measurable and action-oriented targets. Moreover, more action is needed to 
implement the targets nationally, regionally and globally. The post-2010 targets must be strong and operative. They should underscore that we must halt the loss of biodiversity and secure the delivery of ecosystem services for poverty eradication and sustainable development. We also need measurable targets, and a will among all parties to report on the progress. Our target in Norway is to secure all species and ecosystems that occur naturally in the country. The new Government Declaration says that:

The Government will use the Nature Diversity Act to reduce the number of threatened species on the current Red List and to ensure that threatened habitats achieve status as "selected habitat types".

We need to have good results from the COP10 in Japan in 2010.

\subsubsection{Welcome to Trondheim}

Knut Fagerbakke, Deputy Mayor, City of Trondheim

Résumé of speech:

The Deputy Mayor welcomed all the participants to Trondheim, the "biodiversity capital of Norway". He said that active and rapid response is needed to save vital biodiversity and ecosystems. Knut Fagerbakke underlined that outreach and communication to the public is critical, and that the International Biodiversity Year could contribute to this.

He said cities and local communities have an important role in this work, and spoke about Trondheim's signing of the "Countdown 2010" initiative and about three projects in the City of Trondheim. He gave a brief presentation of the key scientific institutions in Trondheim, including the university (NTNU) and relevant research institutions.

\subsubsection{General information by the symposium chairman}

Stig Johansson, Chairman of the Terrestrial Ecosystem Group, Nordic Council of Ministers

I express my sincere thanks to the Secretary of State at the Norwegian Ministry of the Environment, Heidi Sørensen, the Deputy Mayor of Trondheim, Knut Fagerbakke, and the Norwegian Directorate for Nature Management, especially to Lars Ekker, who has been in charge of organising this conference.

As chairman of this symposium, I warmly welcome you to Trondheim for the next two days to discuss Nordic Biodiversity Beyond 2010 - challenges and experiences in a global perspective.

A few words about the purpose and idea behind this symposium:

- In its 83rd plenary meeting, the General Assembly of the United Nations declared 2010 the International Year of Biodiversity and 
designated the secretariat of the CBD as the focal point. It invited Member States to establish national committees for the IYB and encouraged them to use the IYB to increase awareness of the importance of biodiversity.

- The Nordic countries are all signatories of the Convention on Biodiversity and aim to contribute to the goal of halting the loss of biodiversity not only by fulfilling national goals but also by supporting global efforts.

- In 2001, the EU adopted the target of halting the decline in biodiversity by 2010. A similar target was adopted at the Johannesburg summit meeting in 2002.

- We are getting close to 2010 and it is time to take stock of Nordic biodiversity. What has been achieved, how well have we done and what still remains to be done to achieve the goals to which we have committed?

- How can we use our experiences of success and failure to move on?

- An evaluation by the EU Commission has revealed that neither the EU target nor the international target will be met. We need to look beyond 2010, set new targets and goals, and continue focusing on biodiversity.

- In April 2008, the Nordic environmental ministers asked the Nordic Council of Ministers to organise a conference on the current status and perspectives on the future of Nordic biodiversity with eyes on the 2010 target. This is what we are gathered here to discuss for the next two days. The project has been funded by the Nordic Council of Ministers and organised by the Norwegian Directorate for Nature Management.

- The conclusions and recommendations of this conference will serve as part of the preparation processes ahead of the CBD COP10 meeting to take place in Nagoya, Japan, next year, and will be seen as a Nordic contribution to the COP.

During the symposium, we will examine three themes, each of which will be reviewed by experts in the field, under the guidance of separate moderators. Today, we will acquaint ourselves with these themes. The first deals with the status, trends and monitoring tools for Nordic biodiversity. After lunch, we will set about the second theme, Drivers of change. Later in the afternoon, it is time for the third and final theme, Measures and tools for action. Tomorrow starts at 09.00 with a panel discussion on the 2010 targets, after which we will move into working groups.

To prepare for this conference, each Nordic country has prepared a status report on biodiversity in their respective country. These reports will be published on the website of the Norwegian Directorate for Nature Management (www.dirnat.no/symposium2010) together with the conclusions and recommendations of the symposium. 
Once again, I heartily welcome you to the symposium. I hope we will have fruitful discussions on this important topic and thank you all in advance for contributing by sharing your knowledge and experience with the rest of us. By Tuesday evening, we will hopefully be wiser and will discern the next steps needed in the process to halt the loss of biodiversity as soon as humanly possible.

Last but not least, I hope to see you all at the conference dinner tonight, held here at the Rica Nidelven Hotel at 19.00. I now call upon Peter Johan Schei, Director of the Fridtjof Nansen Institute.

\subsubsection{Nordic contribution to international biodiversity implementation and post-2010 processes}

Peter Johan Schei, Director, Fridtjof Nansen Institute, Norway

Iraq became a party to the Convention on Biological Diversity (CBD) on 26 October and Somalia will join in December. Hence, CBD membership is now almost universal.

We should, together, find out the "added value" that can be derived from Nordic cooperation, both in terms of its contributions internationally and through practical cooperation on implementation. If the Nordic countries cannot reach a scientific basis for decision-making and implement international biodiversity obligations, then who can? It is essential to continue efforts to integrate the sectors and achieve mainstreaming, including strengthened and improved communication with the economic sectors and business. 2010 is a critical and busy year for international biodiversity cooperation, and includes such meetings as the 6th Trondheim Conference on Biodiversity on 1-5 February concerning post-2010 biodiversity targets, a special biodiversity session on 20 September during the United Nations General Assembly, and finally the 10th Conference of the Parties to the CBD in Nagoya, Japan, on 18-29 October. It is particularly important to address the underlying drivers of biodiversity loss and secure the involvement of relevant economic sectors. Nordic countries should strive for these sectors to be included in CBD implementation and ensure that they take on their responsibilities.

Post-2010 biodiversity targets will be drawn up and politically approved in autumn 2010, and it is vital that the new targets communicate the economic importance of biodiversity (including showing the costs and effects of not taking the necessary action). It is also essential to integrate biodiversity values and functions into economic frameworks and priorities. Biodiversity and ecosystem services must be well integrated in all political decisionmaking and be perceived as key economic assets for society and for human well-being and development. The ongoing study on "The economics of ecosystem services and biodiversity" (TEEB) and the efforts of its leader, Pavan Sukhdev, are important for bringing this work forward. 
The mutually dependent relationships between climate change and biodiversity are also most important, and interlinks here need to be addressed. Good solutions will require addressing both climate change and biodiversity loss. Efforts to reduce greenhouse gas emissions from deforestation and forest degradation in developing countries (REDD) are an important first step towards addressing ecosystem services such as carbon storage, and Norway's International Climate and Forest Initiative is most welcome. However, there must also be focus on other ecosystems, including wetlands, oceans and agricultural ecosystems, and on more interlinks. The Nordic countries should work keenly on these interlinks, and biodiversity should "ride piggyback" with climate change negotiations.

A stronger science policy platform is needed and the way science is brought into decision-making must be improved. It is regrettable that more progress in developing an international platform of knowledge on biodiversity and ecosystem services (IPBES) has not been achieved, but hopefully a decision on establishing this will come in 2010. The Nordic countries should ensure joint and coordinated support for this work.

Biodiversity and ecosystems should be put into a wider socio-economic context, including trade negotiations under the World Trade Organisation (WTO). There is also a great need for good mechanisms (processes, checkpoints, participation, etc.) for trade-offs between biodiversity and other policy interests. Norway's work on integrated management plans for large marine areas (in particular the Barents Sea Management Plan) is a good example of horizontal cooperation that can enable "soft" trade-offs.

Finally, there is a need to actively follow emerging issues affecting biodiversity and to secure adequate policy and management responses. Current issues include bio fuels, "new landlords" (i.e. richer countries buying up land in poorer countries for production purposes) and "ecosystem tipping points” (also referred to as "planetary boundaries”). 


\subsection{Theme 1 - Nordic biodiversity status, trends and monitoring tools}

Moderator: Berit Lein, Assistant Director General, Norwegian Directorate for Nature Management

2.2.1 State of biodiversity in the Nordic countries - status, monitoring tools, future challenges

Bo Normander, Danish National Environmental Research Institute

The Nordic Council of Ministers has agreed on a common goal to halt the loss of biodiversity by 2010. To document progress towards this target, the state and trends of biodiversity should be measured and evaluated. But what is biodiversity and how can it actually be measured? What is happening in nature? Is the situation getting better or worse, seen in relation to the 2010 target?

NordBio2010, a Nordic project financed primarily by the Nordic Council of Ministers, started in 2007 and culminated in spring 2009 with the Internet publication of a report (http://nordbio2010.dmu.dk and http://www.norden. org/en/publications/publications/2009-509/at_download/publicationfile) prepared by a group of researchers from Denmark, Norway, Finland, Sweden and Iceland. The aim of the project was to evaluate the 2010 target by developing indicators that can describe changes in biodiversity over time in the Nordic countries.

A simple concept was developed to clarify the use of biodiversity indicators. It can describe both dimensions of biodiversity, quantity and quality. Changes in quantity are measured as trends in the area of pre-defined habitats or ecosystems. Changes in quality are measured as trends in species abundance using, for example, selected indicator species, or by a means of measuring quality indirectly, such as the amount of dead wood in a forest or grazing pressure on grasslands. The changes in quantity are currently the easier of the two to measure. All indicators are measured over time to see if they go up or down.

\section{Quantity of biodiversity}

The group reached a common habitat classification system that can be used to measure the biodiversity status in all the Nordic countries (and also in Europe, as the Nordic system is compatible with the European EUNIS habitat classification system). It defines a range of ecosystem types, such as grasslands and mires. Nine major types of habitat were defined: inland surface water, marine, coastal, constructed or highly artificial, farmland, mire, non-vegetated or sparsely vegetated, grassland and forest.

Denmark is the most densely populated country (10\% cities and artificial habitats) and $60 \%$ of the country is farmland. Sweden, Norway and Finland are rich in forests (40-55 \%). Mires and inland waters also take up large 
areas in Finland and Sweden. Bare volcanic bedrock and superficial deposits predominate in Iceland (60\%).

The classification system measures the proportions of each type of habitat, but lack of data and varying definitions of area types between the individual countries are major concerns. Hence, only temporal trends can be derived in some cases. Common for all countries is that the area of constructed habitats has increased markedly, with an average growth of $15 \%$ since 1990. Moreover, the area of grasslands, heathlands and mires has generally decreased in recent decades, mainly because of changes in agriculture and the growth of intensive farming. Greenland and the Faeroe Islands were not included in the project.

\section{Quality of biodiversity}

Success in measuring the quality of biodiversity depends greatly on choosing the most appropriate species. A top-down approach was used in the NordBio2010 project, and relevant indicators were selected for each of the habitats. This method is used in nature monitoring programmes in most of the Nordic countries. As an example, relevant species indicators for a woodland habitat are: woodland insects, woodland birds, tree composition, mosses, lichens, rodents, some mammals (but mammals are usually hunted and are not good indicators because they are greatly influenced by human activity) and some vascular plants. In addition to species indicators, other quality-related indicators include the volume of dead wood, and the proportions of old forest, large trees, clear-cutting and natural forests.

Data on, for example, lichens, mosses, tree composition, vascular plants, woodland insects and the proportion of clear-cutting are poor. Research institutes, NGOs, private organisations and private individuals can provide some data, but transforming them into useful indicators is a huge task. Obtaining data and transforming them into comparable indicators is in fact one of the biggest challenges in the biodiversity field. Thanks to BirdLife and national monitoring programmes, we have quite good trend data on birds. Two examples of quality indicators that closely relate to biodiversity are trends in the area of forest that is more than 140 years old and population trends of common birds. In Finland, old forest shows a decreasing trend from 1975 to 2005, whereas slightly increasing trends are observed in Sweden and Norway since the 1990s. Forest birds have shown increasing trends in all the Nordic countries since the 1980s, whereas farmland birds are generally decreasing.

\section{Combined biodiversity indices}

Quantity and quality can be combined with, for example, quality plotted on the $\mathrm{y}$ axis and quantity on the $\mathrm{x}$ axis. Such diagrams show a loss (or increase) by quantity and a loss (or increase) by quality over time. In theory, it is possible to compute an overall biodiversity index. Taking mires in Finland and Denmark as an example, a decrease in biodiversity quality (measured as 
the abundance of mire birds) can be seen from 1980 to 2000, whereas the quantity (i.e. the area of mires) only decreases slightly during the same period. Lack of data, however, currently hampers the computing of such biodiversity indices.

\section{Challenges}

The NordBio2010 project was an initial attempt to evaluate the 2010 target and to measure the state of biodiversity, but there is still a long way to go. Future recommended tasks include:

\section{Quantity}

- Revise and update national land-use and area statistics

- Agree on definitions of Nordic habitat classes

Quality

- Compute additional indicators based on existing monitoring data

- Harmonise proposed indicators with current and future monitoring in the Nordic countries

Index (easy for policymakers to understand)

- Further develop the biodiversity index, based on quantity and quality

- Build on experience from the Netherlands, Norway and NordBio2010

\subsubsection{Red Lists - biodiversity status, trends and tools for monitoring}

John Atle Kålås and Arild Lindgaard, Norwegian Biodiversity Information Centre, Trondheim

\section{Résumé of presentation:}

The IUCN criteria for drawing up Red Lists of Threatened Species were summarised first. The organisation has also drawn up guidelines for compiling what is called Regional Red Lists, and these are commonly used when National Red Lists are being compiled. It is important to bear in mind that such a National Red List for Threatened Species is a collection of judgements of the risk of species going extinct in the region concerned, which is not necessarily the same as setting conservation priorities. Relevant statements from the IUCN relating to this are, for example, "Assessment of extinction risk and setting conservation priorities are two related but different processes” (IUCN 2003, p. 5), and concerning setting conservation priorities

“... also the status of the taxon from a global perspective and the proportion of the global population that occurs within the region” (IUCN 2003, p. 5); “.. factors such as costs, logistics, changes of success, and other biological characteristics.” (IUCN 2005, p. 11); “... factors such as ecological, phylogenetic, historical, or cultural preferences ..., and legal frameworks ...” (IUCN 2003, p. 5). 
All the Nordic countries have published National Red Lists for Threatened Species using the IUCN criteria. The number of species tested by the IUCN criteria, however, varies greatly from some 15,000-20,000 species in Finland (including Åland), Sweden and Norway, about 6,500 species in Denmark to fewer than 500 species in Iceland, Greenland and the Faeroe Islands. These Red Lists can be used to develop National Red List Indices, which can be useful tools in the task of halting the loss of biodiversity, for instance by raising public awareness. However, to ensure that such indices give information that is relevant for changes in biodiversity, some preparatory work must be done to determine which species should be included. One thing which must be borne in mind is that we are on the northern border of the range of many species, and as many as $20 \%$ of the Red List species in Norway may simply be listed because they are naturally rare. Climate change may improve the quality of Nordic areas for some of these species as they at present have their main populations further south. If such species are included in a National Red List Index, a warmer climate will improve the index, and it is debatable whether this makes sense or not. Another relevant aspect is that much of the countryside is, or has been, strongly influenced by man, and as many as $20 \%$ of the Red List species in Norway may depend on man-made habitats and would probably not appear in this region without human activity.

When Red Lists for species are being compiled, it is also important to identify valuable habitats and important impact factors for the species. Such information is often compiled as part of the work and is very important when determining what needs to be done to halt the loss of biodiversity. Finally, the status for National Red Lists of Habitat Types in the Nordic countries was briefly presented. So far, Finland is the only Nordic country that has published a Red List of Habitat Types (in 2008). Internationally, the work on Red Lists of Habitat Types has not come far, and there are no common international criteria or guidelines for preparing Global or National Red Lists of Habitat Types. However, such work has started recently under the IUCN ("Red List Criteria for Ecosystems"). Norway and Sweden are currently preparing their first Red List for Habitat Types. The most relevant criteria to be used when drawing up such a Red List seem to be: i) change in the quantity of such habitats, ii) change in the quality of the habitat, and iii) limited occurrence (area and extent). These criteria were used in the recent work in Finland. Here, identifying habitat types that are relevant for such assessment also proved a demanding task. Red List Indices may also be developed for habitat types, but this task is only just beginning and will take years to complete. 


\subsubsection{The Nordic input into SEBI 2010}

Frederik Schutyser, European Environment Agency

SEBI 2010 (Streamlining European Biodiversity Indicators for 2010) is a process initiated in 2005, whose first objective was to select a set of indicators to monitor progress towards 2010 in Europe. Its institutional partners are the European Environment Agency (and its European Topic Centre on Biological Diversity), the European Centre for Nature Conservation, the United Nations Environment Programme World Conservation Monitoring Centre (UNEP-WCMC), the European Commission, the Joint Secretariat of the Pan-European Biological and Landscape Diversity Strategy (PEBLDS), and the Czech Republic (as lead country for the Kiev Resolution on Biodiversity's Action Plan on Monitoring and Indicators). The SEBI 2010 process covers 53 countries across Europe.

SEBI 2010 built on the conceptual framework provided by the Convention on Biological Diversity (CBD) and worked with a set of headline indicators within the CBD focal areas.

The process is transparent and involved a wide range of experts from governments, research institutions and NGOs. Stronger direct links with countries to compare national sets with the SEBI set are still being developed. While geographical coverage is good for EU countries and EEA member states, coverage for European countries further east is not satisfactory.

The set must be considered the best available now, but there is certainly room for improvement. Some indicators provide specific measurements and trends on genetic, species and ecosystem/landscape diversity, but many have a much more indirect link to biodiversity. Very few were established specifically to assess biodiversity. Coverage of the components of biological diversity (especially genetic diversity) needs to be improved and the focal areas of access and benefit-sharing and sustainable use need to be strengthened. Establishing stronger links between the indicators would further strengthen policy-relevant conclusions.

Overall, the Nordic countries provide data for many of the indicators and sub-indicators. According to the information available to the EEA at the time of the symposium, the situation is as follows:

\begin{tabular}{lc}
\hline & Number of indicators where data are available \\
\hline Denmark & 25 \\
Finland & 24 \\
Iceland & 7 \\
Norway & 17 \\
Sweden & 24 \\
\hline
\end{tabular}

It should be noted that:

- since some indicators are specifically related to EU policies, non-EU members would have no data 
- EEA has done a survey among member countries to find out how many of the SEBI indicators the country has a national equivalent for. It showed that more data may be available than is coming into the EEA systems at present. Future work will investigate this further.

Data can be disaggregated per country for only a few indicators (see the presentation for details) and data on those indicators are not always accessible for some of the Nordic countries. The mandate for SEBI 2010 is monitoring progress towards the 2010 target at the pan-European scale. It is therefore not surprising that, on the basis of the SEBI set of indicators, no clear assessment can be made of the state of biodiversity in the Nordic countries compared to the rest of (pan-)Europe.

Three areas of interest can be highlighted:

- It is of specific interest to SEBI to have detailed information on the status of biodiversity in the different sub-regions of Europe, such as the Nordic region and the Mediterranean.

- Pan-European countries would benefit from Nordic experience in setting up monitoring programmes.

- Specific data inputs also include data on invasive species from NOBANIS, and work on the Nature Index, Arctic Species Trend Index and Arctic Biodiversity Assessment.

\section{Further reading}

EEA 2007. Halting the loss of biodiversity by 2010: proposal for a first set of indicators to monitor progress in Europe. EEA Technical Report No 11/2007. European Environment Agency, Copenhagen, Denmark. Available at: http://www.eea.europa.eu/ publications/technical_report_2007_11 EEA 2009a. Progress towards the European 2010 biodiversity target. EEA Report 04/2009. Available at: http://www.eea.europa.eu/highlights/pub lications/progress-towards-the-european2010-biodiversity-target/

EEA 2009b. Progress towards the European 2010 biodiversity target - Indicator fact sheets. EEA Technical report No 05/2009. European Environment Agency, Copenhagen. Available at: http://www.eea.europa.eu/publications/p rogress-towards-the-european-2010biodiversity-target-indicator-fact-sheets

\subsubsection{The Finnish biodiversity indicators}

Ari-Pekka Auvinen, Finnish Environment Institute

The first concerted attempt to measure the state and trends of Finland's biodiversity by means of indicators was made in 2005 in conjunction with the evaluation of the country's first National Biodiversity Plan 1997-2005. The first set of 75 biodiversity indicators which was drafted then has subsequently been expanded and improved upon in a cooperative project involving most relevant national research institutes as well as several universities, government authorities and NGOs. Both new and updated existing indica- 
tors are published on the web site www.biodiversity.fi (in Finnish www.luonnontila.fi) as they become available. At present, the set contains some 110 indicators that have been arranged according to the DPSIR framework (DPSIR = Driving force, Pressure, State, Impact, Response) as well as the nine primary habitats present in Finland. Indicators on such crosscutting issues as climate change and invasive alien species will be added in late 2009 and early 2010.

As the indicators have been compiled with few resources, the process has taken place in a step-by-step and trial-and-error fashion. In the course of the project, the indicator collection and web site have gained wide acceptance and support among biodiversity experts. At the moment, it appears that the service may well become a central element in the overall monitoring of biodiversity in Finland. There has been some debate over the interpretation of certain indicators, especially those that relate to the use of economically important natural resources. To increase consensus, groups with expertise on specific habitats have been convened to discuss presentation and interpretation.

Finland's Fourth National Report to the Convention on Biodiversity was based on the Biodiversity.fi indicators. Attempts were made to make the indicators more commensurate and to summarise their message by using specific arrow symbols adapted from the Millennium Ecosystem Assessment. Compiling the indicators has significantly advanced the use and usability of biodiversity monitoring data and has increased cooperation amongst Finnish biodiversity experts. However, the challenge of reaching out to a wider audience still lies ahead as the web site will be officially launched in early 2010.

\subsubsection{The Norwegian Nature Index}

Signe Nybø, Norwegian Directorate for Nature Management

The Norwegian government has decided to have a Nature Index developed to acquire an overview of the state of biodiversity in Norway. The index is intended to serve as an instrument to measure whether the 2010 target is achieved, and will reflect the ecological state and threats to bio-diversity. It will be included in the official statistical indices of sustainable development. The work will also indicate the gaps in biodiversity monitoring in Norway. The task of establishing the index methodology started in late 2007. Specific data already gathered through monitoring and expert judgements were collected in 2009, and the first index will be launched in autumn 2010.

The government wants the index to be widely accepted by the scientific community. This influences the way the project is being organised, i.e. ensuring the broad involvement of scientists. The work involves about 120 scientists who are specialists on one or more indicators or species, and also a number of people who are highly competent in statistics to process the data. The Nature Index (NI) methodology is inspired by the Natural Capital Index (NCI), the Biological Intactness Index (BII) and the Water Framework Di- 
rective (WFD). Biodiversity is measured as quantity (major habitats) and quality (mean species abundance (MSA)), (see also the Nordic indicators project). Surrogates that indicate the abundance of several species are also used as quality indicators. Examples of surrogates are dead wood and encroachment indices for open lowland (grasslands and heathlands). The term "ecological state" is used when we speak of the quality of nature with respect to biodiversity.

A detailed set of criteria has been developed to choose indicators. The NI methodology also focuses on the level of uncertainty in each indicator and the final index to give us some indication of the reliability of the results (as is also done by the IPCC). Both specific data and judgements made by experts are included in the index to enable the judgements to be replaced by specific data when monitoring is established, thereby reducing the uncertainty. The data and methodology will be transparent, i.e. trackable.

Information on the area covered by major habitats is obtained from openly available maps. For the MSA, information is gathered from each species or surrogate from monitoring programmes, official statistics and expert judgements. Data on ecological state indicators are gathered via the Internet and fed into a database. To scale the indicators within the index, we use values for each indicator in the reference state (pristine nature/longterm, traditionally managed conditions). We also determine the sensitivity of each indicator to major pressures to be able to present thematic indices on what threatens biodiversity.

In 2008, a pilot project carried out in central Norway showed that the ecological state was $70 \%$ compared to the reference state. When the index was disaggregated, the ecological state of open lowlands and the ocean proved to be lower than that of the mountains. However, the ecological state of the ocean has improved since 1990. When the index for major taxonomic groups is disaggregated, it is found that vertebrates have a lower index than plants. This is to be expected, as many vertebrates are exploited (harvested). When management is focused upon, it is interesting that it is possible to produce a thematic index that identifies the magnitude of pressures on the ecological state. In central Norway, habitat degradation and overexploitation (fishing and hunting) are the most negative pressures on the ecological state. Pollution and invasive species have few negative effects. The index and the disaggregated indices can be displayed as figures or maps. The pilot study showed that the disaggregated indices give more relevant information for management than the overall index. Data deficiency was easily identified, mostly related to lower taxa species.

The pilot study showed that the method is very flexible and can be used both for areas (countries or regions) that are rich in data and lack data. Furthermore, indices from sub-areas can be aggregated as long as major habitats are defined in the same way in these sub-areas. "Local species" can be used to measure the ecological state as long as criteria for selecting species are met. 


\subsection{Theme 2 - Drivers of change}

Moderator: Axel Wenblad, Director General, Swedish Board of Fisheries

\subsubsection{Main threats to biodiversity in the Nordic countries}

\section{Christian Steel, Norwegian Biodiversity Network (SABIMA)}

The Nordic countries are also suffering loss of biodiversity, and Norway, for example, has recently lost 14 species of bees. Some major drivers of biodiversity loss are (1) pollution; even though this may be decreasing, it remains important for aquatic, alpine and arctic habitats, (2) climate change increases the effects of other drivers (see Maria Mikkelsen's presentation for more details), (3) invasive alien species may be underestimated as drivers of biodiversity loss; some are serious problems and are very hard to eradicate, and (4) land-use changes remain important and many species only have a few suitable and widely dispersed habitats; examples of habitat loss or fragmentation caused by land-use changes can be found in waterways, coastal zones and deltas. It will be very difficult and/or take a long time to bring many ecosystems, such as traditional agricultural ecosystems and forests, back to their original state. The most important priorities after 2010 are to obtain more complete knowledge on species and habitats, develop more comprehensive and better geographical information systems, and improve local government routines (cease occupying new land, restore destroyed habitats, manage cultural landscapes and combat invasive alien species).

\subsubsection{Climate change - what is happening to Nordic nature?}

Maria Mikkelsen, Agency for Spatial and Environmental Planning, Denmark

A project involving scientific civil servants and research scientists from every Nordic country presented its report entitled, Signs of Climate Change in Nordic Nature, on 1 August 2009. The project aimed to identify useful indicators of the impact of climate change on the natural environment of the Nordic countries.

To be acceptable, such an indicator should ideally be representative for the whole Nordic region, responsive to climate change, relevant for politically agreed targets, easily understood, relevant for ecosystems, based on methodology widely accepted by the scientific community, quantitative, available as historical time series, and comparable from one country to another. The indicators were identified using a systematic, criteria-based approach, which is also applicable to a variety of other regions. Fourteen indicators, ranging from deep sea to alpine ecosystems, were found to adequately fulfil the above demands. They were: the growing season, the birch pollen season, migrant birds, moths and butterflies, the tree line, palsa mires, 
snow-bed communities, arctic fox, polar bear, invasive marine species, zooplankton, North Atlantic seabirds, marine fish and freshwater ecosystems. Sufficient information became available too late for one of the seal species in the Baltic Sea to be included in the project, even though it is clearly sensitive to climate change.

The 14 indicators clearly revealed that effects of climate change, like rising temperature and changes in precipitation and wind patterns are already influencing terrestrial, marine, freshwater and other ecosystems. The report showed that climate change is not only affecting a few species and habitats in the Nordic region, some changes are occurring concurrently and on many scales.

Some of the most important and clearest indicators of climate change are:

- The growing season in southern parts of Scandinavia is now starting two weeks earlier, and the same tendency is seen almost everywhere else

- The birch pollen season is a very good indicator and is clearly being driven by the rise in temperature. The season starts increasingly early, and the amount of pollen is rising. This indicator has health implications for many people and its economic consequences are an added motivation. It has been monitored all over the Nordic countries for a long time.

- Some bird populations are decreasing, while other species adapt by changing their migration rhythm. Palsa mires are a sensitive habitat and are declining in distribution

- The arctic fox is a complex indicator because, while the species continues to decline in mainland Fennoscandia despite having been protected for more than 80 years, it is more than holding its own in Svalbard, Greenland and Iceland. The reasons for this are not entirely clear, but the red fox only occurs on the mainland and its range is expanding northwards directly or indirectly due to rising temperatures and its more opportunistic lifestyle.

- Polar bears are threatened by earlier ice break-up

- Cold-water species of zooplankton are clearly decreasing, while warm-water species are increasing. Since the former have their bloom in spring and the latter in autumn, this has major implications for stocks of cod and other fish.

- Freshwater ecosystems are complex and less well understood as regards the implications of climate change on individual species. However, the earlier break-up of ice clearly reflects the overall rise in temperature and is having consequences for the flora and fauna.

What should be done?

- There is a potential for joint, inter-Nordic monitoring systems in addition to the EU initiatives embodied in the Water Framework Directive and NATURA 2000 
- Exchange of knowledge

- Exchange of experience

- Early warning systems

- Elaborate on the criteria presented in this project

- Follow-up the indicators recognised by this project, and start a followup project

- Examine what can be achieved; the broad Nordic understanding should make it easy for us to raise and promote this issue

- A great deal of knowledge exists, but many people engaged in planning roads, buildings, wind farms, etc., are still discussing whether climate change is really taking place; if those who are really putting pressure on nature do not even believe it is a problem, then the problem lies in communication

\subsubsection{Acidification of the oceans}

Jan Helge Fosså, Richard Bellerby, Bjerknes Centre for Climate Research and Tore Jakobsen, Norwegian Institute of Marine Research

Oceans absorb about $25 \%$ of the anthropogenic $\mathrm{CO}_{2}$ added to the atmosphere. Carbonic acid forms when $\mathrm{CO}_{2}$ dissolves in seawater. This phenomenon is called ocean acidification and it can cause seawater to become corrosive to shells and skeletons of numerous marine organisms. Observations and model predictions of ocean acidification show that the changes occur faster and more strongly in high-latitude oceans. A corrosive state will be reached in the northern Barents Sea within a few decades. In the Baltic, this situation is already observed during the winter. Ocean acidification can affect fish both directly through physiological processes and indirectly through changes in the marine food webs (e.g. food quality, quantity and availability), and through deterioration of fish habitats such as tropical and deep-sea coral reefs. Alone, or in combination, this can affect reproduction, growth and mortality in fish populations. Early life stages, hence recruitment, may be particularly vulnerable. This is most regrettable because recruitment governs the dynamics of the fish stock biomass. The northern seas are at risk and the acidification can lead to significant consequences for North Atlantic fisheries that have some of the most important fish stocks in the world (e.g. Atlantic herring, blue whiting and north-east Arctic cod). Fish stocks are most likely to collapse when overfishing coincides with unfavourable environmental conditions that reduce recruitment. Management should therefore aim at maintaining healthy and robust fish stocks that are not overfished and have suffered a minimum loss of genetic diversity. This can secure a high potential for adaptation to changes in the environment. Fisheries management needs to be adaptive and to respond quickly to new environmental knowledge. In a Nordic context, the situation demands cooperation to establish a relevant baseline for monitoring and to initiate research 
programmes. However, adverse effects can only be avoided by limiting future atmospheric $\mathrm{CO}_{2}$ levels.

\subsubsection{Changes in land use and fragmentation}

\section{Erik Framstad, Norwegian Institute for Nature Research}

Human beings already appropriate $>20 \%$ of the terrestrial net primary production (NPP) at the global level and $>70 \%$ in Western Europe. It is therefore not surprising that several studies conclude that changes in land use are the most important threat to biodiversity across a range of habitats in most geographical regions. They lead to a reduction in many types of habitats, a reduction in the quality of remaining ones, and the fragmentation of habitats. Fragmentation leads to a higher rate of reduction in species abundance than the reduction of the habitat itself.

Land-use change in the Nordic countries is mainly related to management changes in agriculture and forestry, and to the expansion of human settlements and infrastructure for transport and energy. Wetlands have been extensively drained for agriculture and forestry over the last 150 years. In agriculture, intensification of the most productive farmland and abandonment of marginal farmland threaten biodiversity. In forestry, the widely applied stand management model has led to a lack of old forests and key habitat resources like dead wood and large, old trees, leading to a reduction in species dependent on such habitat features. Effects of fragmentation of old-growth forest and key resources have also been documented. Over the last 100 years, building of roads, energy production plants and distribution networks, and the general expansion of human settlements have also led to destruction and fragmentation of natural habitats. Settlements and roads tend to occupy the most productive and species-rich natural habitats in the lowlands and along the coasts. However, mountain areas are also increasingly affected by the development of human infrastructure.

Future trends in land use and other environmental pressures like climate change indicate that environmental and other management authorities will need to focus on better physical planning, including more robust conservation areas and securing environmental concerns for biodiversity. As the human use of the landscape and its resources is expanding, leaving less and less of the natural environment as a buffer to accommodate our environmental management mistakes, we need far better knowledge to maintain essential ecosystem services and ensure robust sustainable development. 


\subsection{Theme 3 - Measures and tools for action}

Moderator: Marina von Weissenberg, Senior Adviser, Finnish Ministry of the Environment

\subsubsection{Nature conservation as a tool in the Nordic countries}

Stig Johansson, Chairman of the Terrestrial Ecosystem Group, Nordic Council of Ministers

The Nordic countries play a key role in biodiversity protection in a global context as they are signatories to most, if not all, key multilateral environmental agreements related to biodiversity, most are committed by EU legislation and policies, and all are committed to European and global 2010 targets. However, it is questionable how well the many international commitments are embedded in national policy and not least how they are implemented at the national level.

The Nordic Council of Ministers has an Environmental Action Plan for 2009-2012 which has key links to biodiversity such as sustainable management of natural resources, stopping biodiversity loss, securing ecosystem services, preserving Nordic natural values, and influencing global UN multilateral environmental agreements. The Nordic Terrestrial Ecosystem Group (TEG) also has relevant biodiversity initiatives and activities.

Protected areas may be called the backbone of biodiversity conservation, but there are conflicts with other forms of land use and more work is needed to protect marine areas and restore habitats, ecosystem functions and natural processes. There is a particular need to shift from conservation of sites to conservation of systems and networks, to look beyond the boundaries of protected areas and to introduce more adaptive management. There is also a need to shift from focusing on ecological representation to focusing on ecosystem functions and services. These shifts will be particularly important in the light of climate change, where protected areas can play a role in ecosystem-based adaptation and also for carbon storage. This may be illustrated by an example from Finland on landscape ecological planning and conservation benefits from this approach, by links to the CBD Programme of Work on Protected Areas and by increased EU focus on green infrastructure with ecological coherence and healthy ecosystems.

The April 2009 high-level conference in Athens to frame EU post-2010 biodiversity policy called for a vision on why biodiversity matters, for better understanding of where we are and what we need to do, for a fully functioning network of protected areas and for protecting biodiversity outside protected areas.

Some characteristics of Nordic society may be at risk when it comes to biodiversity beyond 2010. For instance, it may be necessary to revise our current views on a utilitarian relationship in the co-existence between people 
and nature, on whether there is room for intrinsic values and approaches, on retaining the right of common access, and whether we can afford to take good care of nature for future generations?

\subsubsection{NOBANIS - a future tool to combat alien species}

Harry Helmisaari, Finnish Environment Institute

The major reason for the expansion of invasive alien species (IAS) is increasing transport (trade) of species and goods around the world. The changing climate may also influence the increase of IAS. Since IAS and climate change are international problems, they also have to be prevented internationally. IAS poses serious threats since they can influence bio-diversity and ecosystem functions on different levels, from genes to species, and on to the ecosystem level. Some IAS also affects health.

Why do we need NOBANIS?

According to the biodiversity convention (CBD), every country is obliged to prepare a national strategy and action plan as the first step towards minimising the harmful effects of IAS and, thereafter, to take actions to achieve this goal. Each country needs an efficient system to collect, share and distribute information on IAS and experience gained in eradicating them. Since no one country has the resources needed to collect all the data and build up a riskassessment system that covers every potential invasive species, joint actions are needed.

The NOBANIS network (portal) helps us to share and distribute speciesrelated and other information on IAS in our region and find the best ways to minimise their harmful effects. In the future, the web-based NOBANIS portal will also include an Early Warning System to share up-to-date information on the most harmful IAS in the region, thus helping countries in their work of preventing or at least minimising the adverse effects caused by IAS.

\section{What is NOBANIS?}

NOBANIS is a Network and Internet portal to share information on Invasive Alien Species (IAS): www.nobanis.org. The network is based on cooperation between 17 countries (Austria, Belgium, Denmark, Estonia, Finland, the Faeroe Islands, Germany, Greenland, Iceland, Ireland, Latvia, Lithuania, the Netherlands, Norway, Poland, Slovakia, Sweden and the European part of Russia). Each country is responsible for collecting and keeping up-to-date national data on such species, and more than 10,000 records from different ecosystems are currently stored in a searchable database in the portal.

The portal also includes fact sheets about the worst IAS in the region. Experts have so far written fact sheets for 59 species. These contain information on their ecology and means of controlling them. The portal also has 
links to national legislation and to some key sources of information in the literature.

The Nordic Council of Ministers has provided most of the funding for the NOBANIS project. It also funded the Nordic project that resulted in the report, "Introduced species in the Nordic countries" (Nord 2000:13), which was the basis for NOBANIS. NOBANIS is now funded by contributions from members of the group.

\subsubsection{Ecosystem-based marine management in the Nordic countries}

Jorid Hammersland, Marine Unit, Swedish Environmental Protection Agency

With contributions from Johnny Reker, Danish Spatial and Environmental Planning Agency, Jan Ekebom, Natural Heritage Service, Finland, Egil Postmyr, Directorate for Nature Management, Norway, and Jon Resmark, Borough of Lysekil, Sweden

The pressure on marine space and resources is increasing rapidly. Internationally, there has been a call for instruments for better management to secure sustainable use and development. The instrument now being developed and discussed by many international organisations like the EU, HELCOM, OSPAR-ICES and NMR, etc. is Maritime Spatial Planning (MSP).

The principles for ecosystem-based planning and management have evolved from the CBD recommendation in the Ecosystem Approach (EA) and the Malawi Principles. The Ecosystem Approach can be expressed as " $A$ strategy for the integrated management of land, water and living resources and to promote conservation in a sustainable manner". The EA recognises that man is an integrated part of the ecosystem.

Ecosystem-based planning and management should be based on defined principles. Some of the principles that are especially important in the marine environment are:

- Knowledge-based planning and management; in addition to knowledge on marine values, information is needed on human activities and pressures

- Based on clear management objectives that recognise the cumulative effects on ecosystem structure, function and processes

- Coherence between marine and terrestrial planning and management because the state of marine waters largely depends on land-based activities

Maritime Spatial Planning as a tool is defined as a process, builds on the Ecosystem Approach and is forward looking. The process should be open and transparent, involving all stakeholders and covering all maritime sectors - an integrated approach. 
Suggestions for Nordic contributions to the international work on MSP:

- Great deal of knowledge and understanding of marine ecosystem processes

- Pressing need for an ecosystem approach in marine management

- Tradition of democratic stakeholder involvement and transparency

- Cross-border cooperation

- Economic assessments on marine values

\subsubsection{Local contribution to halt the loss of biodiversity}

Terje Klokk, Norwegian Directorate for Nature Management

A project named "Local contributions to meet the 2010 target to halt the loss of biodiversity" started in 2006 and involved 14 local authorities in the five Nordic countries. From the beginning, the emphasis has been on having concrete, local projects and exchanging experience gained from them. Local projects are important internationally, and links have been made to the CBD Global Partnership on Cities and Biodiversity. Several of the local projects were summarised. A web site (http://www.countdown2010.net) gives more details of the main project and the various local projects.

In December 2009, the local authorities will report on the results of 3035 projects, and a final report will be published in April 2010. Key topics are biodiversity restoration, fighting invasive alien species, biodiversity conservation and local biodiversity policy.

It may be concluded that local action is essential if the 2010 target to halt the loss of biodiversity is to be reached.

\subsubsection{The Norwegian postcard campaign in 2008}

Sissel Rübberdt, Norwegian Directorate for Nature Management

Norway performed a postcard campaign in 2008, based on a similar action organised in Denmark in 2007. The mayor of each of the 430 local authorities in Norway received a unique postcard from the Norwegian Minister of the Environment, unique in the sense that there was just one addressee, one text, one species and one photograph. The mayors were asked to take good care of "their" species.

The Directorate for Nature Management implemented the campaign in Norway.

The operation involved the following tasks:

- Choose a unique species for each local authority (although about 30 species were given to two different local authorities); SABIMA proposed the list of species 
- Write a text about each species

- Provide a photograph of each species

- Obtain the names and addresses of 430 mayors

- Design the cards

- Match the text, photograph and Red List category of the species, the names of the mayor and the local authority, and three different languages on a pdf file, and print the cards

- Prepare the media (newspapers, Internet news, TV and radio) for the action

- Prepare Internet pages with the photograph and text from all the cards and a more comprehensive text about the action and what the local authorities can do to protect their species

The most difficult and expensive aspect was acquiring the photographs. Most of the species were rare and could only be found and photographed by "experts".

According to Murphy's Law anything that can go wrong will go wrong. And so it nearly did. The day before I was to deliver the cards personally at the Ministry of the Environment in Oslo (the postal services were not trusted to deliver them), a colleague urged me to check if the printing office had managed to match the local authorities, mayors, species, etc. They had not! The cards had to be printed once more. In a hurry!

\section{Crucial factors}

The operation had one aim: to raise public awareness of threatened species

Why local authorities?

Land-use changes are the most important impact factors related to Red-listed species in Norway. Since most of the land area is managed by local authorities, they are the most important target to address. However, will 430 cards sent to 430 persons have an effect, even if those concerned do have a unique position in society?

It was reasoned that:

- if the local inhabitants were made aware that their borough had been allocated a specific species to "specially protect", they would keep an eye on the activities of their local politicians and council staff

- the "one species case" would hopefully generate the care of threatened species in general

The public thus had to be reached through the media. Sending a postcard depicting a species to each mayor personally is an uncommon thing for the Minister of the Environment to do, and herein lies the novelty value. By doing something unusual, it was possible to make the media take the bait. It was probably also advantageous that many of the species have quite exotic names in Norwegian. 


\section{Action on the TV news}

The campaign was launched by the Minister of the Environment on the evening TV news. We assumed that it was important for the TV news to "show some action”. A local authority near Oslo, which the Minister could visit without spending too much time, had to be chosen. The choice fell on Nesodden, 20 minutes by boat from Oslo, which had been allocated the greatcrested newt (Triturus cristatus). If a newt was caught and held in the hand, there would be enough action to create interest, unlike just an interview, or some people looking at a motionless plant or lichen.

Important factors to make the media take the bait:

- Do things in an unconventional way (the Minister of the Environment is not expected to send postcards to mayors)

- Visual: photographs, action on screen (TV, video)

- Free use of photographs for the media (for a limited period after the action)

- Concrete: species are concrete (as opposed to complex problems)

Did we succeed?

We know we succeeded in making the media take the bait. During the weeks after the operation was launched, news items about it were recorded on:

- Public Internet sites: 14

- Newspapers: 25

- News Internet sites: 62

The national broadcasting cooperation (NRK) has been briefly presenting one postcard species each Sunday through 2009. Local radio stations have had news items. The real aim of the operation was to get the local authorities to protect the assigned species and threatened species in general. The effect of the operation in this respect has not been evaluated.

Finland and Iceland are planning similar postcard operations in 2010.

\section{Follow-up after the campaign}

The Directorate organised a conference in spring 2009 to which mayors and other politicians, as well as people from nature management, scientific institutions and NGOs, were invited. About 300 people attended the conference, and the aim is to arrange similar conferences in the years to follow. 


\subsubsection{Enhancing synergies among biodiversity-related multilateral environmental agreements}

Niko Urho, Ministry of the Environment, Finland

The current architecture of the International Environmental Governance (IEG) is highly fragmented, which has led to inefficiency and duplication of effort. More than 500 Multilateral Environmental Agreements (MEAs) are currently registered in the United Nations. The importance of achieving synergies among MEAs has been highlighted in discussions on reforming the IEG, and also within the conventions themselves.

To date, the most striking example of enhancing synergies among MEAs comes from the chemicals and waste cluster (PIC, POPs and Basel). This has shown that it is essential to involve the Parties if concrete solutions based on national needs are to be found. A "super-COP" of the three conventions will be organised back-to-back with the UNEP special session in Bali in 2010 to take decisions on joint programmatic and administrative activities in the three conventions.

This process for the chemicals and waste cluster shows that significant opportunities for synergies exist among thematically-related MEAs. The chemicals and waste cluster model cannot, however, be applied without modifications to the biodiversity cluster, since the scope and number of MEAs are much larger.

Cooperation at the secretariat level is already under way in the biodiversity cluster. A biodiversity liaison group (BLG) has been established between the heads of the secretariats of six biodiversity-related MEAs: CBD, CITES, CMS, Ramsar, WHC and ITPGRFA. This can be considered a first step in the clustering, but it can also be maintained that as the liaison group functions at the secretariat level it lacks legal authority to create genuine cooperation between the MEAs.

A government-driven clustering process could be launched among the biodiversity-related MEAs to ensure that the concrete needs of the Parties will be taken into account in a transparent and efficient way. The CBD COP10 in Nagoya would be an opportune occasion to launch a biodiversity MEA clustering process. Thematic and programmatic areas for enhancing synergies could include, inter alia, a coherent approach to national reporting under the various MEAs, awareness raising and outreach, as well as capacity building and training.

In recent years, a need to strengthen the science policy interface has been highlighted to achieve more evidence-based decision-making. The Intergovernmental Panel on Climate Change (IPCC) was established in 1988 and provides the UNFCCC with scientific, technical and methodological advice. Apart from the IPCC, there are no fully developed science assessment mechanisms at the international level. 
Discussions are currently taking place with a view to establishing an intergovernmental science policy platform on biodiversity and ecosystem services (IPBES). An independent science policy platform would provide the MEAs in the biodiversity cluster with timely and scientifically credible advice to achieve more coherent and effective decision-making. 



\section{Minutes from the panel session}

\subsection{Introduction}

Session leader: Tone Solhaug, Ministry of the Environment, Norway

The panel consisted of six representatives:

- Stig Johansson, Nordic Council of Ministers

- Jiska van Dijk, Norwegian Institute for Nature Research

- Marina von Weissenberg, Ministry of the Environment, Finland

- Ingeborg Wessel Finstad, WWF Norway

- Ulrika Berggren, Swedish Forest Agency, Sweden

- Ole Dahlqvist Sørensen, Allerød Borough Council, Denmark

Each panel member held a 10-minute presentation about:

- How has the 2010 target affected your work or field? Has the 2010 target been important to you? If so, why? Has the 2010 target gained sufficient political attention in your country?

- How can a post-2010 target be formulated to ensure that your field of work helps to safeguard biodiversity and ecosystem services?

This session did not involve audience participation.

\subsection{Stig Johansson, Nordic Council of Ministers}

The 2010-target has been an extremely important tool for the IUCN. It has brought broad attention to the biodiversity issue also beyond the conservation community. The 2010-concept has been infiltrated into high level discussions and integrated into programmes on different levels.

The Terrestrial Ecosystem Group (TEG) of the Nordic Council of Ministers has addressed the 2010-target through several projects and activities. One of the issues TEG has been dealing with concerns communication of the biodiversity message. There is a lot to be done in this area. The subject has still not achieved sufficient awareness levels outside the environmental field, and it is crucial that we find solutions on how to communicate the biodiversity concept and message to the outside world. The biodiversity targets need to be brought beyond our own "community".

The 2010-target has now become subject for political discussion within our own sphere. It is time to translate strategies into action, and here we 
have not been successful enough. Setting concrete, tangible targets is challenging. It is not enough to have reached the conservation sector. The 2010target needs to be put into practice in all kinds of organizations and institutions in different sectors.

In Sweden the 2010-target has been taken into consideration in the country's Environmental Quality Objectives (Miljömål), which means that progress towards the goals are continuously monitored and evaluated. The Swedish approach serves a good example of how the implementation of goals and strategies can be dealt with on a government level.

Critical points: We need ambitious goals for the future and we should not be afraid to set new goals beyond 2010. But in the end it is the actual deeds and how speeches and documents are turned into action that really counts. The goals need to be translated, communicated, made concrete and broken down into tangible pieces in all different sectors. It is very important that the goals beyond 2010 extend beyond the environmental sector. Which mechanisms and means do we need to succeed?

\subsection{Jiska van Dijk, Norwegian Institute for Nature Research}

Especially during the last 10 to 15 years, there has been growing recognition of the value of information on the status of biodiversity. The recording of species, traditionally done by individual researchers and volunteers, is now often taken care of by state-run monitoring programmes. Advances in technology (e.g. DNA analyses, remote sensing, GIS tools and radar technology) will continue to have a powerful influence on the way we obtain knowledge on biodiversity and how ecosystems function. It is interesting, however, that universities have neglected or even ceased formal taxonomic training even though the need for taxonomists to work on changes in biodiversity is apparent.

During the past decade, scientists have shifted from working alone, with little exchange of data, to working together and exchanging data within and among biological institutes. The scientific community has been mobilised and there is now significant emphasis on consortium building. A good example of this is the establishment of the Long-Term Ecological Research Network (LTER-Europe), which collects biological and environmental data in common, standard ways at different ecological sites all over Europe. At the same time, there is growing recognition that it is necessary to have access to different data series and that data must be shared among different biological institutes (e.g. the ESFRI project LifeWatch, e-Science and Technology Infrastructure for Biodiversity Research). There is also growing recognition of the need to link social sciences to ecology, and numerous interdisciplinary research projects are now undertaken.

Although some sectors, such as fisheries and agriculture, may argue that a great deal is already known and understood concerning biodiversity and how ecosystems function, there are still significant uncertainties and gaps in 
knowledge regarding changes in marine and terrestrial environments, for instance. Interpretation of models and building of scenarios often result in poor predictions of the changes in biodiversity that can actually be expected, and there is little certainty about how robust or flexible ecosystems are in the face of anthropogenic changes, including climate change. To minimise these uncertainties, gaps in our knowledge at the species and community levels still need to be filled in. The research community needs to increase its work on how ecosystems function, ecosystem resilience, how ecosystems respond to disturbances and changes, what the functional links are between key processes and which possible mitigation measures can be implemented. The link between social sciences and ecology should also be further strengthened and elaborated upon. Research on biodiversity, how ecosystems function and their relationship within ecosystem services should be recognised and emphasised. It is absolutely essential that research results are better communicated to policymakers and environment managers and that research results are better implemented (i.e. science-based management). One reason why climate change is more or less accepted at the various levels of society and among most politicians is that the research community concerned with climate change has been able to determine with greater certainty the kinds of climate change the various regions can expect. Research on biodiversity and the way ecosystems function should follow the same path, i.e. we must improve our knowledge and enhance its communication and implementation. In this respect, it is also advisable to extend the various awareness programmes, and take biodiversity and climate change hand in hand, i.e. emphasise the " $A B C$ of Life" (Awareness on Biodiversity and Climate change for the sustainability of human livelihood). In addition to communication being a key topic in the discussion on setting new targets for the loss of biodiversity, these new targets should give the scientific community a strong backbone to continue and extend its research at a high level.

\subsection{Marina von Weissenberg, Ministry of the Environment, Finland}

It is necessary to have enough time to get responses to new targets from policymakers and management, and also from biodiversity and ecosystems. The background document prepared for this meeting contains relevant information on facts and figures which should be looked at more closely. Finland's contribution is a summary of the information given in its 4th national report to the Convention on Biological Diversity (see http://www. dirnat.no/symposium2010/ for more information).

Finland has made some progress on biodiversity issues, partly based on the 2010 target, but perhaps even more so due to implementing the CBD. Successes include enhanced cross-sectoral cooperation (including the establishment and use of a Finnish National Biodiversity Committee, with participation 
from the government, research institutions and society in general), as well as coordinated and "biodiversity-friendly" legislation (for example, in forestry and land use). However, many major challenges in policy, legislation, economic incentives, cooperation and mainstreaming in general remain.

Moreover, it is necessary to achieve better understanding of ecosystem services from scientific viewpoints as well as policy implementation. National-level governance and an advisory structure must be established and developed, and proposals for CBD decisions on this in 2010, including the use of indicators to measure and communicate biodiversity data, are welcome. It is also important for Finland to continue this work, as necessary cross-sectoral learning and dialogue will take time.

Countries are obliged by the CBD and EU to report on the national status and trends in biodiversity. The status of biodiversity is unfortunately showing the same trend in Finland as elsewhere, and there is a need to do better. Biodiversity must be protected, and efforts to achieve this must continue to be effective.

The 2010 target has helped to generate some progress on mainstreaming external development assistance, partly due to the efforts of the Ministry of Foreign Affairs, the WWF and the IUCN. However, environmental issues still need to be given priority in developing countries, and stronger Nordic coordination on this is called for.

Finland is now working on a National Biodiversity Strategy and Action Plan (NBSAP), which currently has 110 actions and also has a target for 2016; the 2010 target was only incorporated into the plan in 2006. Many good indicators are available, and the target has resulted in more political support and plans for campaigns in 2010.

In autumn 2009, Finland approved a communication strategy for the NBSAP for 2006-2016. More effort must be made to communicate our critical concerns and our ambitions. More passion and more positive approaches are needed, and we must communicate our key messages in a brief, understandable and attractive way.

\subsection{Ingeborg Wessel Finstad, WWF Norway}

The 2010 target has created a good platform for Norwegian nongovernmental organisations since the parliament and government have committed themselves to the target, thus facilitating advocacy and pressure. However, the major challenge remains that the target and its implications are not deeply rooted in economic sectors and other global agendas.

WWF Norway believes the 2010 target has made a significant contribution in several areas, including the enactment in 2009 of the Nature Diversity Act (Naturmangfoldloven) as a key guideline for future work, the establishment of the Norwegian Biodiversity Information Centre (Artsdatabanken), new and revised national Red Lists, the drawing up and use of a 
Black List of serious invasive alien species, action plans for selected endangered species, and the preparation of a Nature Index as an instrument for measuring progress. The recent decision by the Ministry of the Environment to protect an endangered butterfly rather than approve a development plan was a positive symbolic case that probably would have been impossible without the 2010 target.

From a conservation viewpoint, it is worrying that the 2010 target is a very defensive aim and the focus should rather be on progress. The Red List and the Black List should become obsolete! The scope and urgency of biodiversity loss, moreover, reflect a need for new targets to show how nature can cope with future development (resilient and robust ecosystems). Targets for 2020 should relate more to quality standards for ecosystems, species and habitats with measurable targets for the sectors based on this on different scales and giving the relevant sectors responsibility for meeting them. The EU Water Framework Directive should form a pattern here.

To develop post-2010 biodiversity targets, it is essential to continue to develop a coordinated and coherent legislative framework (also for land use), to think differently (focus less on biodiversity loss and restrictions on land use and use of resources, and more on restoring ecosystems and being more dynamic and positive), to incorporate true (economic and other) values into decision-making, and to incorporate the cost of land degradation (drawing on advice from the TEEB project). Some progress had been made on using ecosystem services as part of the solution of climate change (cf. e.g. the recent World Bank report on "Convenient solutions to an inconvenient truth").

The need for clear targets for the economic sectors and strong environmental authorities to tackle future battles was underlined. Finally, it is important to bear in mind the opinion of the Norwegian ecologist, Sigmund Hågvar, that future generations would prefer to have healthy nature rather than be left with a precise description of how it disappeared.

\subsection{Ulrika Berggren, Swedish Forest Agency, Sweden}

The Swedish Forest Agency (SFA) is the national authority that is responsible for matters related to the overall sustainability of forests, production, social issues and nature conservation. Its main objective is to maintain sustainable development.

The Nordic countries mainly have managed and fragmented forests (http://www.wri.org/map/worlds-forests-restoration-perspective). Only 1-2 $\%$ of the productive forest in Sweden consists of known key habitats. It should therefore not be a problem to preserve these areas. However, the nation must also take into account that this may sometimes be a major issue from the perspective of a single, small owner of a forested area - a large part or even all of his property may be a key habitat. 


\subsubsection{The Swedish model for achieving sustainability in the forest}

Responsibility is shared between the state and the forest owners. Both must contribute to achieve sustainability; the state must draw up and meet political goals and forest owners must show consideration for nature and protect it without compensation. The main tools are:

1. The law: The Forestry Act and the Swedish environmental code form the basis for preserving biodiversity. The Forestry Act sets the minimum level of consideration for nature and states that the overall goals for production and biodiversity are of equal standing. The Swedish environmental code contains rules for the long-term protection of habitats.

2. Advice to forest owners: Based on the Forestry Act, the SFA advises forest owners how to make their forests sustainable. A minimum level of concern for nature must be maintained, but the SFA also tries to convince forest owners to extend this concern to a level that is on a par with the target for sustainable forests.

3. Long-term protection of habitats: This includes national parks, nature reserves, habitat protection areas and other land set aside by the state, the county administrations, the Swedish Environmental Protection Agency (SEPA), the SFA and local authorities. It also includes land subject to agreements made between the state and forest owners regarding concern for nature, as well as land voluntarily set aside by forest owners without compensation.

4. Campaigns: Campaigns are held to help to meet the goals. An important, current example of cooperation between the forestry sector and the authorities is "Kunskap direkt" (Direct knowledge) hosted by the Forestry Research Institute of Sweden.

5. Forest certification systems: Certification systems are driving forces to voluntarily increase concern for nature in the forests. The two main systems used in Sweden are the Forest Stewardship Council (FSC) and the Programme for the Endorsement of Forest Certification Schemes (PEFC), which give important contributions to nature concern and conservation in the Nordic countries and all over the world. These systems play an important role in raising consideration for nature above the minimum level in the law and are driving forces to set aside areas for nature conservation voluntarily, without compensation from the state.

6. Rural Development Programme: In Sweden, the programme has mainly focused on agricultural sites, but forests are also involved now, with programmes for acquiring skills, forest bio-diversity and promoting broadleaved deciduous forests.

7. Dialogue: Many of the actions needed are not legally binding. Forest owners have to implement them voluntarily. It is therefore crucial for the state to work in dialogue with the sector to give feed-back on follow-ups and discuss proper measures that are needed. The SFA works along with sector councils (national, regional and local levels) that have representatives for forest 
owners, national authorities, administrative boards, forest companies and researchers. Much effort is now being made to further improve the dialogue.

How has the 2010 target affected your work or field? It has been extremely important. It has given increased awareness, changed legislation and tools, and resulted in a key habitat inventory, campaigns, the Natura 2000 network and a strategy for formal nature protection. It has also given a system of national and regional environmental goals for sustainable development with interim targets (www.miljomal.se). These goals and targets are followed up every year.

Political attention: A great deal has been done and much still needs to be done. The Swedish environmental objective system may now be changed. In October 2009, a government inquiry suggested that a political committee be set up to advice the government on environmental policy. It also proposed that the government rather than the parliament should decide targets. The committee would prepare suggestions with the help of groups with broad representation from the authorities, sectors, scientists and NGOs.

How to formulate and work on goals: Goals have to be SMART, specific, measurable, attainable, realistic and timely. There should be overall policy objectives, long-term visions and interim targets. We must cooperate better than before. Let the sector decide how to reach the targets for which they are responsible. This creates concern, responsibility and a drive to take action. The state should also ask how it can help the sector to reach the goals.

\subsection{Ole Dahlqvist Sørensen, Allerød Borough Council, Denmark}

Allerød is a small municipal borough in Danish terms, but Danish local authorities are quite large in a Nordic perspective and have a great deal of responsibility for nature conservation. Allerød consists of both rural and urban areas and has approximately 24,000 inhabitants. It has an abundance of valuable natural history, including two NATURA 2000 sites, a plant species that occurs nowhere else in Denmark, and numerous species of endangered flora and fauna. In 2007, Danish local authorities took over much of the responsibility for nature management when the county administrations were abolished. Nature management was widely expected to suffer through lack of priority in the struggle for funding with schools and care of the elderly, which are traditional municipal tasks. However, surprisingly it was local politicians who first broached the issue of bio-diversity, and they proved to be very well informed, not least through the postcard campaign run by the Danish Ministry of the Environment.

The postcard campaign really worked. It gave politicians an incentive to focus on biodiversity problems and a good feeling of responsibility for the task. Right from the start, this attitude gave the administration a good agenda to present ideas for projects and to get them approved. 


\subsubsection{Example of how the 2010 target has affected our work or field}

The following environmental projects may be singled out:

- A Green Council was set up to formulate and discuss many ideas and projects to support the natural environment in informal meetings with NGOs and local representatives for state forest agencies, etc.

- An action plan was formulated to eradicate the giant hogweed, based on specific national legislation to fight this plant.

- Allerød could not succeed in saving biodiversity alone; it had to work alongside other municipal administrations. We joined a Life + project in cooperation with four other local authorities in Denmark and partners in Estonia. It is important to make politicians understand that the Countdown 2010 target cannot be attained just by working locally. Wider cooperation is essential.

- In general, local authorities need an overall strategy to achieve the Countdown 2010 target. When it became a partner in the "Green City" network, Allerød made a political commitment to stop the loss of biodiversity in 2010 and increase biodiversity by 2015. The Green Cities are seven municipal authorities in Denmark (and originally one in Sweden), which are cooperating to try to fulfil this commitment. Not least the task of documenting a halt in the loss of biodiversity and a subsequent increase in it requires thorough data collection and monitoring.

- Allerød drew up a prioritised list of specific species to focus upon, and this will form the basis of our future Countdown 2010 work.

\subsubsection{Challenges}

- Local authorities need help in the monitoring effort. This is a real challenge. The Ministry of the Environment, which has the responsibility today, has reduced the monitoring effort to concentrate strongly on the NATURA 2000 areas. Existing data are rarely sufficiently up-to-date to be able to prove that loss of biodiversity has been halted or biodiversity has increased.

- Another serious problem is the task of prioritising species on the local level. Some groups of species may be left out due to lack of local expertise and lack of funding for external experts. For instance, one of our partners had to leave fungi out of their monitoring effort because there were no local experts to document their trend.

- Local ownership is important for putting focus on the project and getting people involved. We have evaluated how sellable the prioritised species are; for instance, if a species "looks good" we have tended to put priority on it rather than on an "ugly" species, because it is easier to sell. This is not a scientific approach, but a necessary way to achieve success and public awareness of the task of preserving biodiversity. 
- Only one invasive species (giant hogweed) is being combated by national legislation in Denmark today. This is not enough. Other invasive species will become a huge problem in the future. More law enforcement is recommended (some potentially major invasive species can now be purchased at garden centres and nurseries, which just increases the problems associated with them and the costs that will eventually be incurred by the authorities to fight them).

- Allerød is behind in the work of keeping the public informed of what is taking place. This will be a major issue in 2010. Other local authorities are further ahead with this task of increasing public awareness of the need to preserve biodiversity. State agencies will hopefully put this on the agenda next year when a new "Countdown" is expected to be initiated, so that local authorities will be inspired to provide even better information. Allerød has considered copying the postcard campaign locally (for instance, in schools).

\subsection{From the discussion and questions from the Chair}

Tone Solhaug thanked the panel members for their contributions on lessons learned from the 2010 target and proposals for developing post-2010 biodiversity targets. She also noted the crosscutting advice on knowledge, communication, indicators, mainstreaming, SMART targets and positive targets. She asked everyone to bear in mind the challenge to make a system of targets that can be used throughout the world. Tone Solhaug also commented on the need to engage the business sector and to communicate better as regards economy.

Marina von Weissenberg said that there should be a vision that does not undermine the need to halt biodiversity loss, for example by 2050. She stressed the need to have some tangible milestones on the way there, and that these must include all the five main drivers of biodiversity loss (pollution, land use and habitat loss, climate change, invasive alien species and overexploitation). We should learn from climate change and the UNFCCC how to present and use specific figures and time frames. She also noted that we should not miss the opportunity to build on the political momentum we have from the 2010 target, at least in the Nordic countries. She suggested continuing the support for developing indicators and monitoring to provide knowledge on the status and trends of biodiversity, and added that we need to show other sectors that it is not only "we" who have a problem ...

Stig Johansson touched upon integrating biodiversity concerns in development cooperation, noting that, while there should be room for more Nordic cooperation, we must also respect the needs and priorities of developing countries and be wary of imposing solutions for a "global good". 



\section{The recommendations of the working groups}

In the afternoon, the participants split into four working groups. Based on proposed topics for discussion and their experience from a Nordic perspective, they were expected to arrive at some concrete recommendations for future action (see the Appendix for more information about the various groups and the topics they discussed).

The topics discussed by the four groups and their principal recommendations are outlined below.

\subsection{Group 1 - Setting new targets for biodiversity beyond 2010}

Chair: Bo Normander, Senior Adviser, Danish National Environmental Research Institute

Co-chair: Tone Solhaug, Senior Adviser, Norwegian Ministry of the Environment

Biodiversity conservation needs inspirational, but tangible, post-2010 targets to focus our common efforts, and a supportive policy and an institutional framework for its implementation. The goal of this workshop is to facilitate discussion about how to set up post-2010 biodiversity targets.

What will happen after 2010? Will there be a 2020 or a 2050 target? We still have a long way to go. Biodiversity is still declining, both globally and in the Nordic countries. The issue of climate change has most attention at the global level. Very few are talking about biodiversity. This is the experience in for example Denmark, the host country for the COP15 climate conference in December 2009.

These issues were discussed during the session:

- Some thought that a 2020 target was too far ahead, but everyone seemed to agree that it was more realistic than 2050. We should have a long-term vision put in a positive way. For example: "We need rich biodiversity and healthy ecosystems for human well-being”. Biodiversity and ecosystems belong together.

- Can the Nordic countries have stricter sub-targets than the EU?

- "Halting the loss of biodiversity" should be included in new targets. However, we should also have a positive long-term vision. If the 
message comes from heads of government, it will be stronger. We should be better at using international institutions to bring out our message.

- Signs that biodiversity is improving in the freshwater environment in Denmark show that it is possible to halt the loss of biodiversity.

- If the new target is only a vision, the politicians will not feel obliged to meet it. We therefore need sub-targets. Another deficiency of the CBD is that it is not legally binding. It has no enforcement mechanisms.

- We should build on existing knowledge and the good experience we have. We should have clear targets.

- Biodiversity is one of the solutions to climate change. We need to reform our government structure and work more closely with our colleagues on climate change. Can we have measurable targets that are similar to those for climate change, and can they be made legally binding?

- We should be better at pointing out the cost of not doing anything (e.g. Pavan Sukhdev on the economic value of coral reefs). We should therefore integrate the economics of ecosystem services in our work.

- How about offering incentives? Like Finland, give awards for achievements in biodiversity. Bring out the success stories.

- There should be transparency from the process of collecting data to reporting.

- Communicate better what DPSIR (Driving force, Pressure, State, Impact, and Response) is all about.

- The SEBI (Streamlining European Biodiversity Indicators) 2010 framework is good and includes fisheries and agriculture, but where are indicators for other sectors like tourism?

- We should formulate sub-goals for sectors. We need adaptive management. We produce reports on status, but we need an integrated system between monitoring and implementation.

- We should not use a year as the baseline, but a condition like the definition of "good ecological status" from the Water Framework Directive.

- Would a science policy interface be useful at the Nordic level?

- We need to communicate these issues and the importance of halting the loss of biodiversity to a wider audience. Examples like Sukhdev and the coral reefs will show people how urgent the problem is. Map the health of ecosystems to demonstrate the urgency of the problem to the general public.

- Perhaps we should have a Nature Index to measure trends in nature in all the Nordic countries?

- We should be better at communicating the effects of the loss of biodiversity and the kinds of consequences this can have. 
Key recommendations:

- The main target should be "good ecological status" in each habitat in 2020

- We need clear, positive and measurable sub-targets

- Biodiversity and ecosystem services should be included in 2020 targets

- Rich biodiversity and healthy ecosystems are needed for human wellbeing

- We should formulate targets for sectors

- The efficient governance of biodiversity and ecosystem services needs instruments to bridge gaps between sectors, actors, levels and scales and between science and policy

- Conserving biodiversity is part of the solution to climate change; we need to reform our government structure and work more closely with our climate change colleagues

- We should be better at pointing out the cost of not doing anything (e.g. Sukhdev and coral reefs)

- We need clear information from the political level on what needs to be reported

- We should be better at communicating the effects of the loss of biodiversity and the consequences this can have

\subsection{Group 2 - Setting new targets for drivers of change beyond 2010}

Chair: Reidar Hindrum, Senior Adviser, Norwegian Directorate for Nature Management

Co-chair: Marina von Weissenberg, Senior Adviser, Finnish Ministry of the Environment

How can a future goal be formulated to address the drivers of change and the obstacles to change?

- The future target must be measurable

- Build on existing indicators

- We have many measuring instruments, but we do not have much driving focus on what to do with them

- More taxonomic training in universities and museums to combat alien species; this is not included in this work

- The time issue is important - important to have a deadline

- Important to have easily measurable indicators to monitor progress (Greenland, for example, has limited financial resources) 
- Time must be defined; it could also be precisely formulated to be easy to interpret and implement

- Important to have overall goals, and also sub-goals

- Important to have a good network to share information so that the wheel is not invented many times

- Think big enough

- We must bridge the gaps between the environmental sectors and other sectors; alliances with the more powerful sectors are needed because they are equally dependent on biodiversity and ecosystem services

- Targets must be clear, easily measurable and communicated, easy to interpret and implement, and they must be made readily understandable by the general public. The sectors must be involved. Bring in other disciplines like psychology and communication.

- Habitat change issue. It is important to bear in mind that it is not sufficient to just stop the loss; we must also rehabilitate biodiversity and improve its conditions.

- A baseline is important. Measuring progress. Also has to do with scientific credibility.

How can the post-2010 target framework be established to facilitate the involvement of other sectors (agriculture, fisheries and forestry)?

- Involvement of other sectors. Formulate the post-2010 target so that it is easily understood and easier to implement. Sectoral ministers must become involved in formulating the target. This work must be coordinated by the Ministry of the Environment.

- Sector responsibility is the main issue, but a scientific baseline is needed

- Give a recommendation to the Nordic ministers to adopt a framework for the sectors to develop goals and targets

- Challenges to implement "sustainable use" are not being well applied in the Nordic countries. We must get the attention of the economic sector because it is the main coordinator of business and sectoral issues.

How can the post-2010 target framework be established so that it creates synergistic policies that consider the contribution that biodiversity and ecosystem services provide for adaptation and mitigation to climate change?

- Communication

- Sustainable use is a key aspect

- Synergies with the UNFCCC

- Eco-security, economy, income and health - opportunities

- Bring ecosystem services into the national economy

- Well-functioning ecosystems are a natural insurance against the impacts of climate change 
- Importance of resilient ecosystems

- The Nordic ministers need to continuously address the issue of climate change and biodiversity (e.g. permafrost and the Arctic). Synergistic issues between CBD and UNFCCC and the recommendations from the Copenhagen meeting will be important.

- Ecosystem-based adaptation; a win-win situation between climate and biodiversity

\subsection{Group 3 - Main instruments for mainstreaming biodiversity}

Chair: Axel Wenblad, Director General, Swedish Board of Fisheries

Co-chair: Sigurdur Thrainsson, Head of Division, Office of Policy and International Affairs, the Icelandic Ministry for the Environment.

\subsubsection{Mainstreaming}

- The owners of the targets should be the prime ministers

- Lift the issue of biodiversity from the environment ministries to the government

- The overall goals must be set by the governments; an example is the Swedish environmental target (“miljømålen”)

- An example from Norway is that the Ministry of Finance reports on sustainability, which helps to link ecology to economy

\subsubsection{National committees}

- Appoint national committees composed of representatives from relevant sectors and NGOs, and scientists, to discuss issues related to biodiversity and sustainability (the Finnish model)

- The committees should be given a mandate to discuss and coordinate biodiversity issues, and should meet regularly

- Coordination of strategies can also be part of their work

- The Nordic countries should inform the rest of the world about the setting up of the national committees on biodiversity

\subsubsection{Sectors}

- Evaluate the national coordination of work related to biodiversity

- Modernise sector-related Acts and Regulations to include biodiversity issues; the new Acts relating to biodiversity will not work before the sectors are engaged in their implementation

- Formulate national strategies for the drivers of biodiversity loss 
- Involve the sectors early in discussions on new targets for biodiversity; be aware that you may reach understanding, but not consensus

- Bear in mind that there are different levels of targets

- Discuss at which level responsibility should be lying , at the national, the regional or the local level?

- Involve the sectors in processes related to biodiversity, informing them that sustainability is beneficial to them in the long term; a good example is the dependency of fisheries upon biodiversity

- Use language the sectors understand

- Use management plans to safeguard biodiversity; these must be incorporated into relevant sectors

- Targets must be knowledge-based and should involve the sectors

- Be aware of when to involve the sectors

\subsubsection{Business}

- Instruments should be introduced to set standards that include sustainability and biodiversity

- Biodiversity should be made part of marketing

- Focus on the standards that apply to the language of business

- Business is risk-management driven; do not be prescriptive, but let business be involved in the processes related to sustainability

- Involvement by businesses should be voluntary, and biodiversity should be integrated into their products or marketing by getting them to donate a certain amount of their income to biodiversity

- Do not subsidise activity that degrades biodiversity, but channel it onto sustainable pathways

- Scenarios can be used to show how much can be harvested from a resource; help businesses to understand that setting long-term targets will enhance the opportunities for harvesting

\subsubsection{Communication}

- Communicate that the International Year of Biodiversity is not merely a communication campaign, but should also be used to implement the 2010 target at national and local levels

- Communicate the values of ecosystems and the results of TEEB

- Recognise proper communication instruments

- Inspire the various parties to take ownership

- Communication is important, and measures should be taken to reach the general public by choosing an appropriate language for communication and explaining key terms

- The term biodiversity is not properly understood by the general public 
- Identify a basis for communication that involves relevant terms and prioritise the main messages; the Red List, for example, can be a relevant basis for communication

- Be specific on how to safeguard the biodiversity, and identify the drivers of change, from which sector they are influenced and what kind of action needs to be taken to preserve biodiversity

- Inform about climate change and biodiversity issues at the same time

- Focus on both species and types of habitat

\subsubsection{Regional and local levels}

- Set targets that apply on different levels

- Focus on land-use management and local authorities; the key to either saving or destroying biodiversity lies within these levels

- Incorporate the biodiversity targets into day-to-day work

- Involve the local authorities, and acknowledge the challenge of building knowledge and capacity to the right levels

- Develop strategies to educate different levels, related to the implementation of legislation, for example

- Local authorities are important when it comes to strategies

- The local authority is the most important level to manage land-use issues

- Defined targets (like the Swedish environmental goals) are recognised as an administrative instrument to guide the lower levels of authorities, but they do not communicate to the general public

\subsubsection{International level - scientifically based}

- Raises many questions

- There is a need to strengthen the scientific basis for setting new biodiversity targets

- Do we need a biodiversity panel under the CBD? The IPCC reports have helped to mainstream the discussions and bring the world forward. MA was a good project, but we now lack a collective drive.

- Assessment reports contribute to mainstream discussions on an international level and are also positive in a communication perspective

- Where should the panel be placed in the CBD hierarchy and what role should it play?

- Discussions should perhaps be held on whether the panel should be an independent body?

- SUBSTTA has changed into a political body, and an evaluation of its mandate can be suggested

- Establishing a panel would also help to solve the challenge of communication

- Should we use existing systems, or change the systems? 


\subsection{Group 4 - Facilitating local action as an instrument}

Chair: Stefan Skog, Director of the Environmental Division, Vanda Borough Council, Finland

Co-chair: Terje Klokk, Senior Adviser, Norwegian Directorate for Nature Management

How can the role of local communities in achieving the future target to halt the loss of biodiversity be emphasised?

- Local participation is crucial

- Ensure a good knowledge-base on the local level

- Commitments - do we need clearer legislation and regulation on the local level?

- Develop a system that ensures local participation

- Make local authorities understand that biodiversity is a resource by giving concrete examples

- Use human resources and local expertise, and create networks with neighbouring local authorities

- Develop and make available toolkits for local authorities

- Establish partnerships with all relevant stakeholders, including companies, local authorities, schools and NGOs

- The main threat is changes in land use and the most important stakeholders are local authorities, landowners and sectors; find solutions by using land-use plans

- Clear demands on the content of the land-use plan

How can issues related to halting the loss of biodiversity be communicated in a way that encourages local interest and involvement?

- Ensure the presence of local competence on biodiversity that can work across municipal borders

- "Spider in the net" - across municipal borders

- Create local meeting places to develop good dialogue

- Communicate biodiversity by simplifying the message based on the uniqueness or character of the borough concerned - "We've something other boroughs don't have"

- Use ambassadors such as local authors, pop stars and artists

- Highlight biodiversity in the education plan

- Focus on ecosystem areas

How can the various Nordic countries, the Nordic Council of Ministers and the Parties to the CBD provide better support to cities and other local au- 
thorities to implement the National Biodiversity Strategies and Action Plans (NBSAPs)?

- Create meeting places for local authorities

- Create instruments for local authorities

- Show that local authorities are important

- Bring the local level to the international arena

- Design mechanisms for a bottom-up strategy

- Challenge the local authorities (e.g. the postcard campaign)

- Obtain uniform data that are comparable 



\section{Conference conclusions and recommendations}

\subsection{Summary}

- The Nordic countries will not meet the 2010 target to halt the loss of biodiversity

- A similar, ambitious target is needed beyond 2010, emphasising the need for healthy ecosystems for human well-being

- Halting the loss of biodiversity, together with efforts to tackle climate change, must be raised to an overarching, high-level political goal, which is continuously monitored and reported by governments across all sectors in society

\subsection{General conclusions}

\subsubsection{The 2010 target}

- The Nordic countries will not reach the 2010 target to halt the loss of biodiversity

- It has, however, been useful for raising awareness and generating important actions for the sustainable use and conservation of biodiversity

- It has been included in national policies and strategies in the Nordic countries, which have influenced primary programmes in the environmental sector, but other sectors have so far done little to integrate biodiversity concerns

- The 2010 target has stimulated monitoring and reporting work, recognising the need to improve our knowledge-base

\subsubsection{Beyond 2010}

- The target to halt the loss of biodiversity is still valid and even more urgent than before

- A similar, ambitious overall target beyond 2010 is required, which emphasises the need for healthy ecosystems for human well-being

- The new targets should be relevant to all biodiversity-related conventions

- Halting the loss of biodiversity, together with measures to combat and adapt to climate change, must be raised to an overarching, high-level 
political goal, which is continuously monitored and reported by governments across the sectors in society

- The target must be described in a powerful message communicating the consequences of the loss of biodiversity beyond the environmental constituency to ordinary people and to other sectors and stakeholders in society

- Stakeholders and processes in society, such as the business and consumer sectors, must be involved in formulating goals and taking responsibility for halting the loss of biodiversity

- Efficient governance of biodiversity and ecosystem services needs instruments to bridge gaps between sectors and scales, and between science and policy, and there is a need for adaptive governance that continuously generates and makes use of newly acquired knowledge on ecology

- There must be procedures and mechanisms in society to assess, make choices and arbitrate between increasingly conflicting uses of natural resources and ecosystem services

- There is a need for improved and more authoritative scientific knowledge on the status and trends in biodiversity

\subsection{Specific recommendations}

\subsubsection{Nordic Council and Nordic Council of Ministers}

- Biodiversity, along with climate change, must be made into a highlevel, overarching Nordic political agenda

- The Nordic countries should develop a strategy, "Biodiversity towards 2020", as a vehicle for joint international action, action within Europe and at the national level; the strategy should emphasise the importance of local actions

- The establishment of a joint Nordic Platform for Biodiversity and Ecosystem Services to generate high-level scientific policy should be explored

- A joint Nordic effort to develop the work on invasive alien species, such as NOBANIS, into a common EU and pan-European platform should be considered

- As land use is a major driver in the loss of biodiversity, better land-use planning is the key to counter the negative impacts on biodiversity, and the role of local authorities should be emphasised in this respect

- Business and biodiversity, including the role of consumer-driven markets in achieving a sustainable use of biodiversity, should be highlighted in the Nordic cooperation

- A Nordic project should be started to exchange experience in effective communication strategies regarding the challenge of biodiversity 


\subsubsection{National actions}

- Biodiversity, along with efforts to tackle climate change, should be elevated to the highest political level to ensure that goals related to climate change and biodiversity are integrated into sector goals, plans and programmes

- There is considerable scope for joint Nordic efforts to develop for example indicators and monitor change, and to incorporate these in European-level initiatives

- Establish national biodiversity committees that include all major stakeholders to ensure that biodiversity issues are addressed by society in a coherent way

- Improve and restore ecosystems that are important for biodiversity and ecosystem services

\subsubsection{Nordic actions in a global context}

- Common Nordic support to establish an Intergovernmental Platform on Biodiversity and Ecosystem Services that includes mechanisms to use Nordic cooperation and experience to strengthen its role

- Develop an overarching Nordic strategy and framework agenda for biodiversity and climate change for coherent Nordic actions, including in development aid

- Support a major communication initiative to take the results of the "Economics of Ecosystems and Biodiversity" (TEEB) study to policymakers and decision-makers in the Nordic countries and in developing countries as part of the joint Nordic development agenda

- The Nordic countries should be proactive and be good examples of how regional collaboration can be used to halt the loss of biodiversity 



\section{Norsk sammendrag}

Den 26.-27. oktober 2009 var Nordisk ministerråd vertskap for et nordisk symposium om biodiversitet som ble avholdt i Trondheim. Tittelen på symposiet var "Nordisk biodiversitet etter 2010 - utfordringer og erfaringer i globalt perspektiv”. Målet var å gjøre opp status for biodiversitet i Norden og rette blikket mot veien videre fra 2010. For å starte dette arbeidet var om lag 70 deltakere fra alle de nordiske landene samlet i Trondheim i to dager. De representerte offentlige myndigheter, frivillige organisasjoner og forskningsinstitusjoner som alle er involvert i målet om å stanse tapet av biodiversitet i de nordiske landene.

Symposiet hadde fokus på tre tema:

- Nordisk biodiversitet: Status, trender og overvåkingsverktøy

- Drivkrefter for endring: Hva er statusen for drivkreftene som påvirker biodiversitet på en negativ eller positiv måte? Videre handling?

- Tiltak og handlingsverktøy: Hvilke tiltak har de nordiske landene gjort for å bevare og forbedre biodiversiteten? Hvordan forholder disse seg til 2010-målet?

Den første dagen ble det holdt innlegg rundt disse tre temaene. Den andre dagen ble deltakerne delt inn i fire arbeidsgrupper, og de ble bedt om å komme frem til anbefalinger for videre handling basert på de foreslåtte diskusjonstemaene. Disse anbefalingene skulle være et nordisk innspill til europeiske og globale prosesser som leder frem mot politiske avgjørelser på høyt nivå høsten 2010 om fastsetting av nye biodiversitetsmål for tiden etter 2010 (fastsettes ved COP10 av CBD og/eller FNs Generalforsamling). Anbefalingene skulle også være en praktisk oppfølging og implementering av politikken i de nordiske landene og under Nordisk ministerråd.

Gjennom dette symposiet kom det tydelig frem at de nordiske landene ikke har nådd målet om å stanse tapet av biologisk mangfold innen 2010. Resultatene viser allikevel at målet har vært viktig i dette arbeidet, ikke minst gjennom å bidra til økt oppmerksomhet rundt tapet av biologisk mangfold. 2010-målet har stimulert til økt innsats innen naturovervåking og rapportering og har også blitt inkludert i mange nasjonale programmer og strategier. 
Selv om målet ikke ble nådd, viser resultatene fra symposiet at det fortsatt er svært aktuelt. Utfordringene er fortsatt store og det er et sterkt behov for et nytt mål som kan stake ut kursen videre for arbeidet med å stanse tapet av biologisk mangfold. Et nytt mål må være ambisiøst og relevant for alle konvensjoner som er relatert til biodiversitet, og må bidra til at stans av tap av biodiversitet løftes til et høyt nivå. Målet må kommuniseres på en tydelig måte slik at budskapet når frem til alle lag av samfunnet. Kunnskapsnivået må forbedres og man må få på plass mekanismer som kan brukes til å avveie mellom konfliktfylte former for bruk av naturressurser. 


\section{Appendices}

\subsection{Background paper for workshop 1: Setting new targets beyond 2010 for biodiversity}

\subsubsection{Trondheim, 26-27 October 2009}

Chair: Bo Normander, Senior Adviser, Danish National Environmental Research Institute

Co-chair: Tone Solhaug, Senior Adviser, Norwegian Ministry of the Environment

\subsubsection{Introduction}

The 2010 biodiversity target set by the Convention on Biological Diversity has been successful in mobilising some action towards stemming the loss of biodiversity globally. Since the 2010 target was set in 2002, the world and its awareness of the importance of biodiversity have changed dramatically. However, it has also become apparent that this target has a number of weaknesses that Parties to the Convention on Biological Diversity (CBD) will need to address in the next iteration of a biodiversity conservation target at their 10th Conference of the Parties (COP10) meeting to be held in Nagoya, Japan in October 2010.

The goal of this workshop is to facilitate discussion about how to set up a post-2010 biodiversity target framework. The CBD framework and its associated focal areas, goals and targets will form the basis for discussion. Furthermore, the role of the Nordic countries and their contributions to European and global processes towards the COP10 meeting in 2010 will be reflected.

Biodiversity conservation needs an inspirational, but tangible, post-2010 target to focus our common efforts, as well as a supportive policy and institutional framework for implementation. When the policy areas of biodiversity conservation and climate change are compared, many significant differences become apparent. The international climate debate is much more advanced and has a longer record for setting up measureable policy targets and indicators. Hence, the UN Kyoto Protocol uses quantitative and legallybinding targets for the reduction of greenhouse gas emissions. A wide range of climate change indicators are in place and agreed upon globally, including indicators for temperature change, sea-level rise, concentration of $\mathrm{CO}_{2}$ in the atmosphere and emissions of greenhouse gases. In the field of biodiversity, clear quantitative targets and indicators are lacking and no countries are legally bound to fulfil biodiversity goals. 


\subsubsection{Issues for discussion}

- How can the vision, targets and new goals for biodiversity be ambitious, yet realistic?

- What is the time frame $(2020,2050$ or...)?

- How do we express the urgency of the situation?

- How can achievement be relatively easily measured?

- How can we develop an indicator framework?

- What can we learn from the current CBD indicator framework, the European SEBI 2010 indicator framework and the NordBio2010 framework?

- How is biodiversity measured?

- In what ways can the DPSIR (Driving force, Pressure, State, Impact and Response) framework be applied?

- hich baselines should be used?

- Should 1990 (or 2000 or pre-industrial time or ...) be chosen as the base year?

- What is the spatial scale?

- How do we operate at a local, national, regional and/or global level?

- How can new goals be legally binding?

- A legal framework, quotas or...?

- How can the Nordic countries contribute?

- What is the process towards the CBD COP10 meeting in 2010?

- Where should we adopt the vision, targets and goals? GA SS (Sept. 2010), CBD COP10 (Oct. 2010) or UN GA late- or post-2010?

- How can we strengthen synergies between biodiversity related conventions in the future and the new vision, targets and goals 2010+?

\section{Recommended reading}

The IUCN paper: Options for a new vision for biodiversity, is highly recommended as it provides a good starting point for discussion.

European Commission 2008: A mid-term assessment of implementing the EC biodiversity action plan - SEBI 2010 biodiversity indicators. SEC 2008/3045. http://ec.europa.eu/environment/nature/b iodiversity/comm2006/bap_2008.htm

European Commission 2008: Environment: major additional effort needed to halt biodiversity loss by 2010. EC press release 16.12.2008.

http://europa.eu/rapid/pressReleasesActi on.do? reference $=\mathrm{IP} / 08 / 1988 \&$ format $=\mathrm{H}$ TML\&aged=0\&language=EN\&guiLang uage $=$ en
European Council 2001: Presidency Conclusions - Gothenburg, 15 and 16 June 2001. SN 200/1/01.

http://europa.eu/europeancouncil/index_en.htm

IUCN 2009: 2010 is almost here - now what? Consultation: Options for a new vision for biodiversity.

http://cmsdata.iucn.org/downloads/iucn_2 010_options_paper_draft.pdf

UNEP 2002: Report of the sixth meeting of the Conference of the Parties to the Convention on Biological Diversity. Annex I. Decision VI/26.

http://www.cbd.int/doc/?meeting=COP06 Background paper for workshop 2: Setting new targets beyond 2010 for drivers of change 
7.1.4 Trondheim, 26-27 October 2009

Chair: Reidar Hindrum, Senior Adviser, Norwegian Directorate for Nature Management

Co-chair: Marina von Weissenberg, Senior Adviser, Finnish Ministry of the Environment

\subsubsection{Introduction}

Notwithstanding some successes, it is clear that the global community will not meet the 2010 biodiversity target despite a few bright spots of good news. The Millennium Ecosystem Assessment demonstrated that the many drivers of biodiversity loss have compounded the negative impact on biodiversity and are increasing in intensity; halting biodiversity loss is therefore an increasingly challenging task.

Land-use changes, eutrophication, unsustainable use of biological resources, overexploitation of marine ecosystems and invasive alien species continue to be the main drivers of biodiversity loss, and they are increasingly exacerbated by climate change. All these drivers must be addressed within any post-2010 framework.

The goal of this workshop is to facilitate discussion about how to set up new targets beyond 2010 for drivers of change. Based on the proposed topics for discussion and experiences from a Nordic perspective, the working group participants are expected to arrive at some concrete recommendations for future actions.

The targets for these recommendations are:

- Nordic input to European and global processes leading towards highlevel political decisions for setting post-2010 biodiversity targets in autumn 2010 (to be set by the COP10 of the CBD and/or the United Nations General Assembly)

- Practical follow-up and policy implementation in the Nordic countries and under the Nordic Council of Ministers.

\subsubsection{Topics for discussion}

- How can future goals that directly address the drivers of change and obstacles to change be formulated?

- How can the post-2010 biodiversity target framework be established so that it facilitates the involvement of business sectors like agriculture, fisheries and forestry? 
- How can the post-2010 biodiversity target be established so that it creates synergistic policies that consider the contribution that biodiversity and ecosystems make towards climate change adaptation and mitigation at local, national and global levels, taking into account that biodiversity and ecosystem services are critical for regulating our climate?

\section{Recommended reading}

IUCN 2009: 2010 is almost here - now what? Consultation: Options for a new vision for biodiversity. http://cmsdata.iucn.org/downloads/iuc n_2010_options_paper_draft.pdf

\subsection{Background paper for workshop 3: Tools for mainstreaming biodiversity}

\subsubsection{Trondheim, 26-27 October 2009}

Chair: Axel Wenblad, Director General, Swedish Board of Fisheries

Co-chair: Sigurdur Thrainsson, Head of Division, Office of Policy and International Affairs, Icelandic Ministry for the Environment

\subsubsection{Introduction}

All the relevant sectors must contribute actively if biodiversity is to be saved. Leaving the issue of biodiversity and its loss solely in the hands of the environment ministries will mean that highly relevant sectors like agriculture, climate change, development cooperation, energy, forestry, fisheries, human health, disaster prevention, the military, commerce, finance and so on will probably be neglected.

The post-2010 biodiversity target should be established in a way that provides ownership and gives each sector the ability to implement action towards targets that are relevant for it. This entails mainstreaming an improved understanding of the benefits arising from biodiversity and ecosystem services and the cost of their loss, as is found relevant for the various sectors. There must also be mainstreaming of the identification of consequent cost-effective policy options for the conservation of biodiversity and ecosystem services.

The goal of this workshop is to facilitate a discussion on this important subject. Based on the proposed topics for discussion and experiences from a Nordic perspective, the participants of the working group are expected to arrive at some concrete recommendations for future actions.

The targets for these recommendations are:

- Nordic input to European and global processes leading towards highlevel political decisions for setting post-2010 biodiversity targets in 
autumn 2010 (to be set by the COP10 of the CBD and/or the United Nations General Assembly)

- Practical follow-up and policy implementation in the Nordic countries and under the Nordic Council of Ministers

\subsubsection{Issues for discussion}

We would particularly like the working group to discuss the following:

- How can national biodiversity policies and incentives be formulated and implemented so that they relate better to relevant sectors, including forestry, fisheries and agriculture, to promote markets for environmentally friendly products, and to promote sustainable natural resource management?

- How can we strengthen the use of economics as a tool to achieve biodiversity policy goals (ecosystem services, TEEB)?

- How can the post-2010 biodiversity targets be formulated so as to be relevant for important sectors, and be established so that they facilitate the ability of each sector to implement action towards the targets relevant to their sector?

If time permits, the following may also be discussed:

- Do the various sectors have the relevant indicators, reporting and evaluating systems that can or should be expanded?

- Difficult trade-offs may have to be made, for instance between the protection of habitats for biodiversity and the transformation of ecosystems for human needs. Some ecosystem transformation is inevitable, but the impact on biodiversity will depend on how development is carried out. How can we develop and implement good trade-off methodologies to help decisions to be made with full comprehension of both the upside and downside of a particular choice? What are good examples from the Nordic countries?

\section{Recommended reading}

Mainstreaming Biodiversity into Sectoral and Cross-Sectoral Strategies, Plans and Programmes Module B-3. Version 1 July 2007.

www.cbd.int/doc/training/nbsap/b3train-mainstream-en.pdf

The Economics of Ecosystems and Biodiversity (TEEB). See http://www.teebweb.org/

IUCN 2009: 2010 is almost here - now what? Consultation: Options for a new vision for biodiversity. http://cmsdata.iucn.org/downloads/iuc n_2010_options_paper_draft.pdf 


\subsection{Background paper for workshop 4: Facilitating local action}

\subsubsection{Trondheim, 26-27 October 2009}

Chair: Stefan Skog, Director of Environmental Division, Vanda Borough

Council, Finland

Co-chair: Terje Klokk, Senior Adviser, Norwegian Directorate for Nature Management

\subsubsection{Introduction}

The intention of this workshop is to provide policymakers on local, national, regional and international levels with a set of recommendations on how to facilitate local action. Concrete actions at the local level are essential if we are going to meet future targets. Local municipal authorities play a central role, since they are responsible for land-use planning and control much of the local biological diversity. They are also the natural arena for mobilising and involving the public.

Based on the proposed topics for discussion and experience from a Nordic perspective, the participants of the working group are expected to arrive at some concrete recommendations for future actions.

The targets for these recommendations are European and global processes towards the COP10 meeting, the Nordic countries and their local authorities, and the Nordic Council of Ministers.

\subsubsection{Issues for discussion}

- How can the role of local authorities in achieving the future targets to halt the loss of biodiversity be emphasised?

- How can issues related to halting the loss of biodiversity be communicated in a way that promotes local interest and involvement?

- How can the various Nordic countries, the Nordic Council of Ministers and the Parties to the CBD better support cities and other local authorities in their implementation of National Biodiversity Strategies and Action Plans (NBSAPs)?

\subsubsection{Pre-suggested recommendations and reflections}

- We need more and better information about the local environment on plants, birds, fish, mammals, insects, water, catchment areas, landscape analysis and cultural history. 
- We need cooperation at the local level - between local ornithologists, biologists, anglers, hunters, schools and nature schools, businesses and students in colleges and universities, for example.

- We need to get local politicians and the general public interested.

- We need both expertise and resources for conservation work at the local level.

- Land-use planning is an important instrument; local authorities can control the development as regards the local environment. The term "biodiversity" should appear in local land-use planning.

- Restoring wetlands, combating the overgrowing of farmland and reclaiming contaminated industrial sites and landfills are important means of anchoring nature conservation locally.

- Green areas are important ecological networks. Local environmental and recreational areas are particularly important for children, the disabled and the elderly.

- New information technology (IT) should be used to cooperate on and share knowledge on local biodiversity.

\section{Recommended reading}

Local Authorities and Biodiversity. CBD homepage http://www.cbd.int/authorities/
IUCN 2009: 2010 is almost here - now what? Consultation: Options for a new vision for biodiversity.

http://cmsdata.iucn.org/downloads/iuc n_2010_options_paper_draft.pdf 